PNL-4812

UC-94e

\title{
Thermophysical Behavior of
}

St. Peter Sandstone:

Application to Compressed

Air Energy Storage in an

Aquifer

R. L. Erikson

December 1983

Prepared for the U.S. Department of Energy under Contract DE-AC06-76RLO 1830

Pacific Northwest Laboratory Operated for the U.S. Department of Energy by Battelle Memorial Institute 


\title{
DISCLAIMER
}

This report was prepared as an account of work sponsored by an agency of the United States Government. Neither the United States Government nor any agency thereof, nor any of their employees, makes any warranty, express or implied, or assumes any legal liability or responsibility for the accuracy, completeness, or usefulness of any information, apparatus, product, or process disclosed, or represents that its use would not infringe privately owned rights. Reference herein to any specific commercial product, process, or service by trade name, trademark, manufacturer, or otherwise, does not necessarily constitute or imply its endorsement, recommendation, or favoring by the United States Government or any agency thereof. The views and opinions of authors expressed herein do not necessarily state or reflect those of the United States Government or any agency thereof.

\author{
PACIFIC NORTHWEST LABORATORY \\ operated by \\ BATTELLE \\ for the \\ UNITED STATES DEPARTMENT OF ENERGY \\ under Contract DE-AC06-76RLO 1830
}

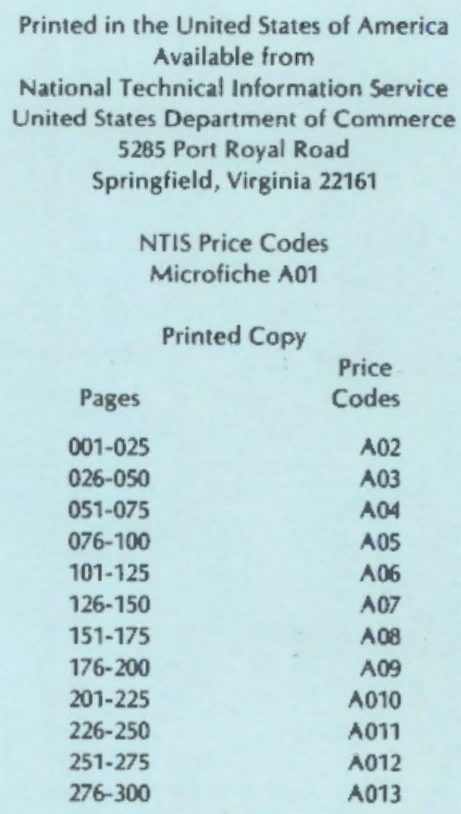


THERMOPHYSICAL BEHAVIOR OF ST. PETER SANDSTONE:

APPLICATION TO COMPRESSED

AIR ENERGY STORAGE IN AN

AQUIFER

R. L. Erikson

December 1983

Prepared for the U.S. Department of Energy under Contract DE-ACO6-76RLO 1830

Pacific Northwest Laboratory

Richland, Washington 99352 



\section{FDREWORD}

Compressed air energy storage (CAES) is a technique that transfers energy from off-peak to peak demand time for electric utility systems. It incorporates modified state-of-the-art gas turbines and underground reservoirs--aquifers, salt cavities, or mined hard rock caverns. The compressor and turbine sections of the gas turbine are alternately coupled to a motor/generator for operation during different time periods. During off-peak electric demand periods, base load plants not using petroleum fuels provide energy to compress air, which is stored in the underground reservoirs. During peak-load electric demand periods, the compressed air is withdrawn from storage, mixed with fuel, combusted and then expanded through the turbines to generate electricity. Because the turbine is not required to drive a compressor, this concept reduces peaking plant consumption of petroleum fuel by more than $60 \%$.

Since 1975, the Pacific Northwest Laboratory (PNL) has served as the U.S. Department of Energy's lead laboratory in managing research and development efforts to support CAES technology commercialization.

A substantial part of the CAES Technology Projects is represented by the Reservoir Stability Studies. The goal of these studies is to ensure long-term stable containment of air in the underground reservoirs used in conjunction with CAES plants. The specific objective is to develop stability criteria and engineering guidelines for designing CAES reservoirs in each of the three major reservoir types, including aquifers, salt cavities, and mined hard rock caverns.

Three parallel studies have been performed. Each contained a survey of the state-of-the-art and numerical and experimental studies. The mined hard rock and salt studies were completed and final criteria documents have been issued. The aquifer study has aiso been completed as a generic study, but has been extended to include a specific field experiment, the Pittsfield Aquifer Test. 
The objective of this document is to demonstrate the laboratory reservoir simulation capabilities developed during previous comprehensive research projects. The specific experiments discussed here were performed in support of the design, construction and operation of the Pittsfield Aquifer Field Test. The actual St. Peter sandstone that constitutes the air storage formation was examined in this study. The material was cored from the Pittsfield site during exploration and development activities in 1981 and 1982.

The reservoir simulator, the Porous Media Flow Loop located at Pacific Northwest Laboratory, was specially designed to simulate the CAES aquifer air storage environment after a determination that such a capabitity was necessary to quantify reservoir materials response of interest to CAES reservoir designers. Simultaneous control of stress, temperature, humidity, and air flow allow precise evaluation of in situ responses. This capability is unique to this facility. The facility is presently in a standby mode at the laboratory, and is available to the industry to perform experimental studies as one the elements of the extensive geosciences experimental capability available at Battelle.

The information presented herein is being used, in conjunction with results of actual field tests and other data, as the basis for the porous media reservoir stability criteria. An interim version of this criteria and guidelines document (PNL-4707) was issued by PNL in May 1983.

T. J. Doherty, Manager

Compressed Air Energy Storage Project

Pacific Northwest Laboratory 


\section{ACKNOWLEDGMENT}

The author wishes to acknowledge R. A. McBride and C. E. Haines for their assistance in calibrating and operating the Porous Media Flow Loop. The help provided by R. D. Allen, S. C. Blair, T. J. Doherty, L. D. Kannberg, and J. A. Stottlemyre in reviewing this report is greatly appreciated. 
SUMMARY

The long-term stability of a sandstone reservoir is of primary importance to the success of compressed air energy storage (CAES) in aquifers. The purpose of this study was to:

- develop experimental techniques required for the operation of the CAES Porous Media Flow Loop (PMFL), an apparatus designed to study the stability of porous media in subsurface geologic environments,

- conduct experiments in the PMFL designed to determine the effects of temperature, stress, and humidity on the stability of candidate CAES reservoir materials,

- provide support for the CAES field demonstration project in Pittsfield, Illinois, by characterizing the thermophysical stability of Pittsfield reservoir sandstone under simulated field conditions.

The results suggest the physical properties of the Pittsfield reservoir rock (St. Peter sandstone) were altered to some extent when subjected to the simulated Pittsfield, Illinois, field conditions. The vertical permeability of this sandstone increased from 0 to $7 \%$ during heating to $180^{\circ} \mathrm{C}$ at $1200 \mathrm{psi}(8.3 \mathrm{MPa}$ ) and then decreased (7 to $15 \%$ ) during cooling to room temperature. The greater decrease during cooling (hysteresis) resulted in a permanent permeability loss that was characteristic of this sandstone during cyclic temperature fluctuations. The magnitude of permeability hysteresis was greatest for the first temperature cycle and decreased during subsequent cycling. After three temperature cycles to $180^{\circ} \mathrm{C}$, the sandstone lost approximately $20 \%$ of its initial permeability.

The effect of pore pressure on permeability was determined for approximate air injection pressures ( 300 psi) anticipated at the CAES field demonstration. The permeability was not significantly changed by varying pore pressure from 20 to 300 psi $(0.14$ to $2.07 \mathrm{MPa})$ at a constant 
confining stress of $1200 \mathrm{psi}(8.3 \mathrm{MPa})$ and temperature of $20^{\circ} \mathrm{C}$. This suggests the permeability of the reservoir sandstone at Pittsfield will not be greatiy affected within the proposed range of injection pressures at ambient temperature.

The permeability of St. Peter sandstone also decreased under increased stress and during stress cycling at $20^{\circ} \mathrm{C}$. Permeability decreases of approximately $25 \%$ occurred as the effective stress was increased from 700 to 6700 psi (4.8 to $46.2 \mathrm{MPa}$ ). Most of this permeability loss is recoverable as the stress is released. However, a permanent permeability loss (hysteresis) also occurs during stress cycling. Moreover, the permeability-stress hysteresis is also a maximum for the first cycle and decreases with repeated cycles. After three cycles to an effective stress of 6700 psi (46.2 MPa), the cumulative permeability loss was $13 \%$.

Simultaneous measurement of sample strain and permeability during stress cycling suggest the permeability behavior is related to the mechanical response of the sandstone matrix. The strain-hardening behavior of this sandstone under hydrostatic stress results in larger matrix compressibility at low effective stresses. The higher compressibility causes greater permeability reductions at low stress levels. Secondly, the sandstone behaves more elastically with repeated stress cycling. The near-elastic behavior of the sandstone during the later stress cycles results in decreased permeability losses of the rock.

Although the results of this study impiy cumulative permeability losses of 13 to $20 \%$ under the cyclic temperature-stress conditions of CAES, these losses are small relative to the initial permeability of the sandstone. Moreover, none of the samples studied exhibited any evidence of severe physical disaggregation after being subjected to cyclic temperature-stress conditions. Untess permeability losses or physical alterations increase with further cycling, the permeability changes noted in this study should not significantly impair CAES reservoir performance. 


\section{CONTENTS}

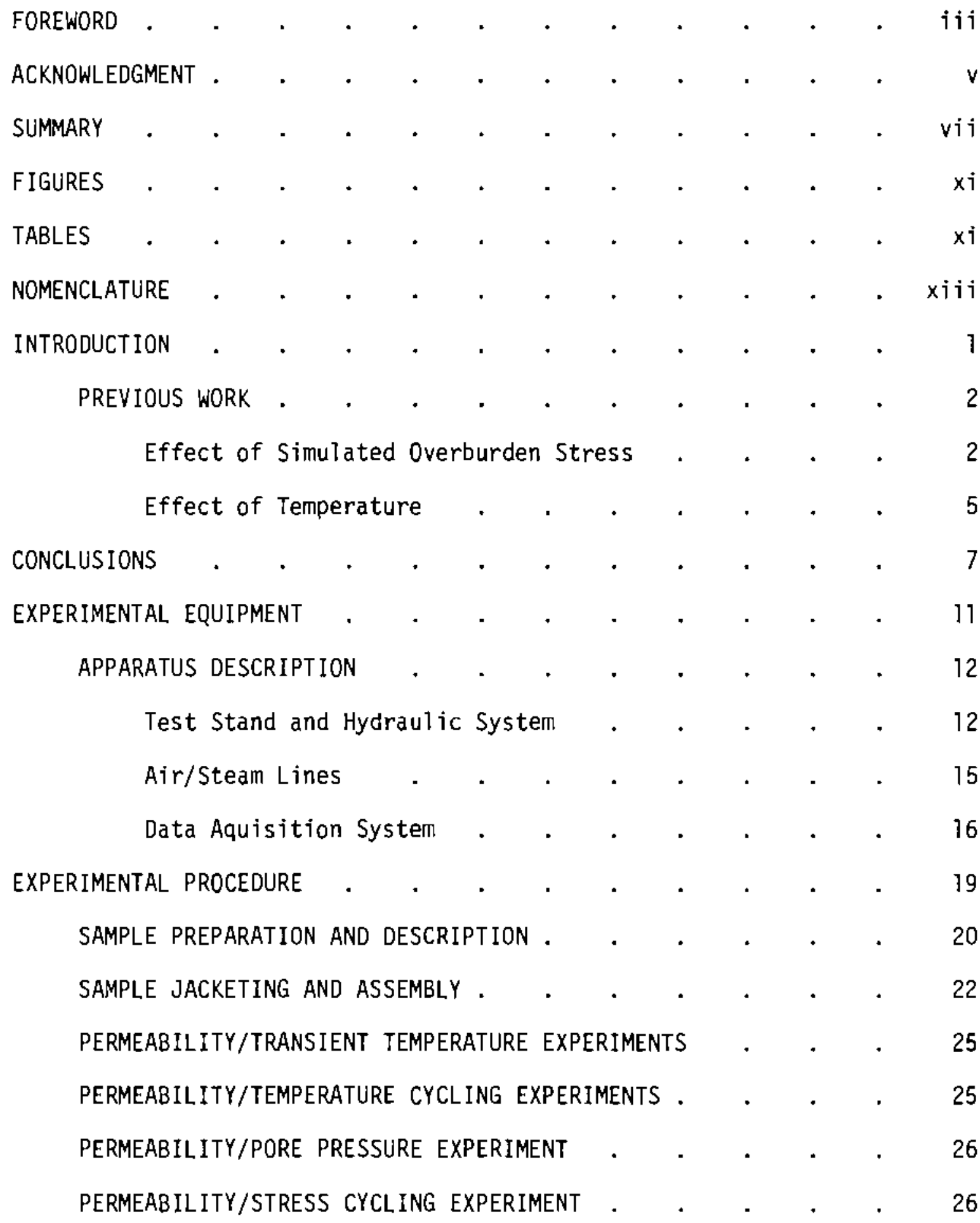




\section{CONTENTS contd}

\begin{tabular}{|c|c|c|c|c|c|c|c|c|c|c|c|}
\hline \multicolumn{3}{|c|}{ METHODS OF CALCULATION } & . & - & - & . & . & . & - & - & 27 \\
\hline & Sermeability & - & - & . & . & . & - & $\cdot$ & . & • & 27 \\
\hline & iumidity & . & . & . & . & . & - & • & • & • & 29 \\
\hline & Sample Strain & - & . & . & . & - & - & $\cdot$ & • & • & 31 \\
\hline RESULTS AND & DISCUSSION & . & - & . & - & . & - & $\cdot$ & - & • & 35 \\
\hline EFFECT & T OF TEMPERATL & & - & - & . & . & " & " & • & . & 35 \\
\hline EFFECT & OF PORE PRES & SURE & . & . & . & . & - & $\bullet$ & • & - & 40 \\
\hline EFFECT & OF CONFININE & STRES & SS AND & & & CYCL & & $\theta^{\circ}$ & & • & 42 \\
\hline REFERENCES & . & . & . & - & . & . & $\cdot$ & • & • & $v^{\circ}$ & R. 1 \\
\hline
\end{tabular}




\section{FIGURES}

1 Porous Media Flow Loop Schematic . . . . . . . 13

2 Load Frame and Triaxial Pressure Vessel . . . . . . 14

3 Instrumentation Panel and Data Aquisition System for Porous Media Flow Loop . . . . . . . . 17

4 Sample Assembly Schematic . . . . . . . . . . 23

5 Deformation Jacket Assembly Schematic . . . . . . 24

6 Permeability Versus Transient Temperature . . . . . 36

7 Permeability Versus Temperature for Sample 657 . . . . 36

8 Permeability Versus Cyclic Temperature for Sample 703 . 37

9 Permeability Versus Pore Pressure for Sample 703 . . . 41

10 Permeability Versus Confining Stress for Sample 664 . 42

11 Axial Strain Versus Effective Stress for Sample 664 . . 44

\section{$\underline{\text { TABLES }}$}

1 Porous Media Flow Loop Capabilities. . . . . . . 11

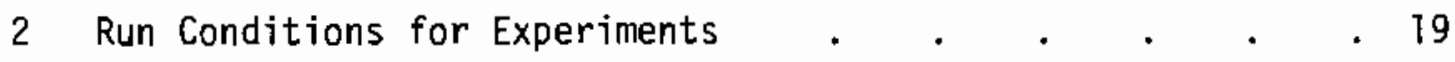

3 Bulk Density and Apparent Porosity of Laboratory Samples of St. Peter Sandstone . . . . . . . 21 


\section{NOMENCLATURE}

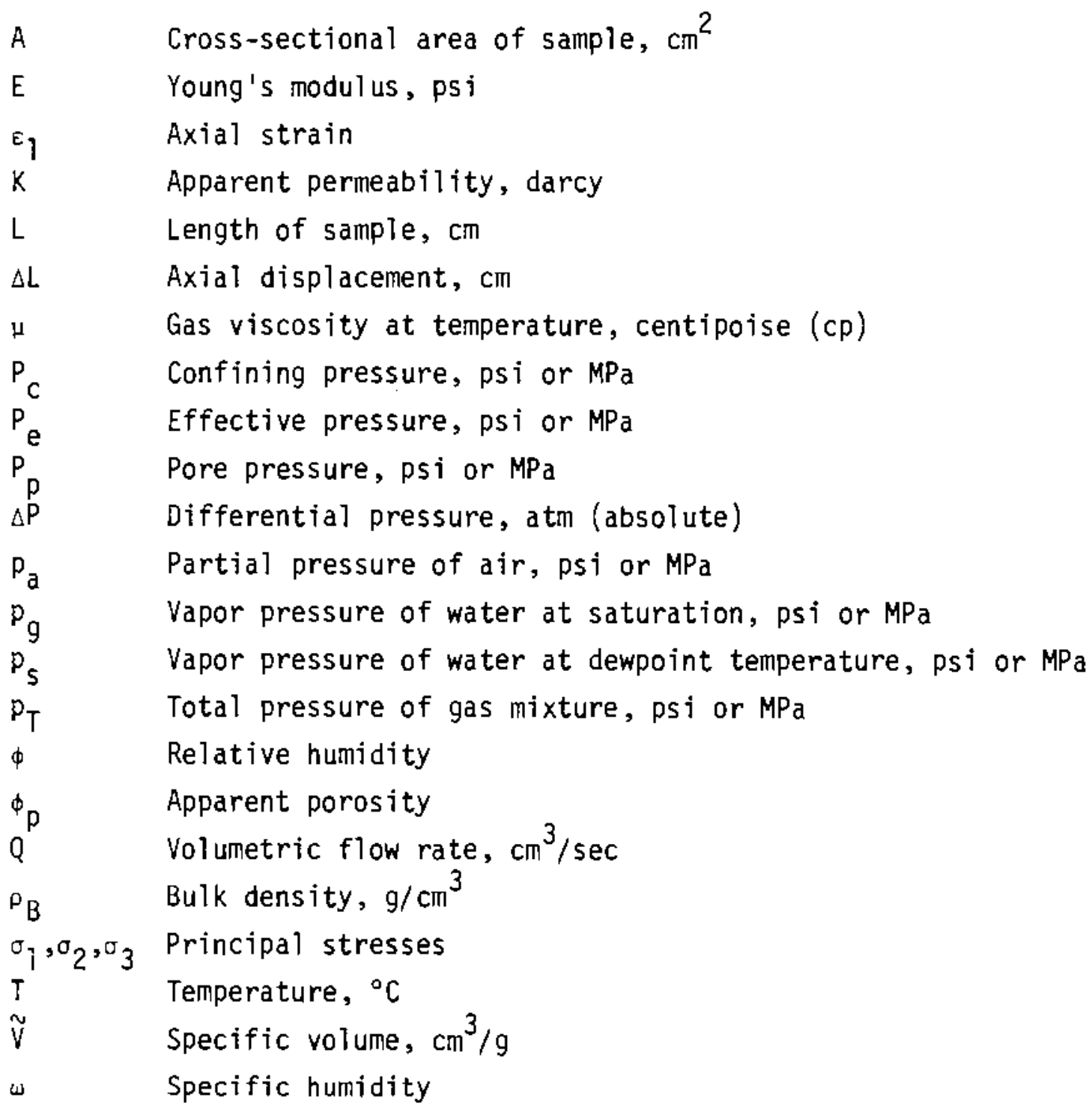




\section{THERMOPHYSICAL BEHAVIOR OF ST. PETER SANDSTONE: APPLICATION TO CDMPRESSED AIR ENERGY STORAGE IN AN AQUIFER}

\section{INTRODUCTION}

The knowledge of the thermophysical behavior of aquifer sandstone and its potential physical alteration is of primary importance in determining long-term reservoir stability for the application of the compressed air energy storage (CAES) technology in aquifers. The physical integrity of the rock matrix must remain intact during frequent (daily or weekly) pressure, temperature, and humidity cycles. Injection temperatures may vary from formation temperature to $200^{\circ} \mathrm{C}$ and storage pressures from 300 to 2200 psi (2.0 to $15.1 \mathrm{MPa}$ ) (Allen et al. 1983). The effect of fluctuations in these variables on the matrix permeability and thermomechanical properties of aquifer sandstones must be evaiuated.

Many of the rock thermophysical properties can be studied in the laboratory where simulated physical parameters (e.g., temperature, pressure) can be easily controlled. Accurate laboratory simulation of aquiferCAES conditions, however, requires sophisticated experimental equipment. The equipment must be able to simulate the approximate stress conditions anticipated in the field, as well as the flow of air through aquifer material and the pressure-temperature-humidity regime of CAES. It is also essential that properties of the rock be measured as the sample is subjected to the temperature-stress conditions of CAES. The CAES Porous Media Flow Loop (PMFL), a "flow-through" experimental system, was designed to meet these requirements. Constructed at the Pacific Northwest Laboratory, the PMFL was used as a laboratory simulator of field conditions anticipated for the aquifer-CAES technology.

In this report, preliminary results of laboratory experiments conducted in the PMFL are presented. The experiments described are in direct support of a CAES field demonstration test in Pittsfield, Illinois. The 
fie?d test involves the development of an air bubble at depths of 600 to $700 \mathrm{ft}$ in the $5 \mathrm{t}$. Peter sandstone. Cyclic air injections at temperatures of $50^{\circ}, 100^{\circ}, 150^{\circ}$ and $200^{\circ} \mathrm{C}$ and at pressures less than 300 psi (2.07 MPa) are planned while monitoring the temperature, air pressure, and humidity in different regions of the reservoir (Allen and Doherty 1982).

The measurements conducted in the laboratory have focussed on determining the effects of temperature, stress, and pore pressure (i.e., injection pressure) on the permeability of the St. Peter sandstone to hot, dry air. The sandstone samples used in this study were actual field borehole samples of St. Peter sandstone obtained from the injection zone at the Pittsfield site. Moreover, the experimental conditions of the tests (e.g., temperature, pressure) were chosen in concert with conditions anticipated at the field site. The results of the laboratory measurements may be useful in understanding the nature of flow through porous rock, in laboratory-field data correlations, and in predicting long-term reservoir stability.

\section{PREVIOUS WORK}

Previous laboratory studies have simulated the flow of fluids through porous rock under geologic conditions similar to those expected in a CAES environment. In many of these studies, the effects of stress and temperature on the permeability, bulk compressibility, and pore compressibility of reservoir sandstones were measured. These studies can provide useful information on factors affecting the permeability of reservoir sandstone and may facilitate interpretation of the data obtained in this study. This section briefly reviews literature pertinent to the effects of stress and temperature on the permeability of sandstone.

\section{Effect of Simulated Overburden Stress}

Early laboratory measurements of the permeability of porous rocks were routinely obtained at $T$ atmosphere confining pressure. Researchers concerned about the applicability of these measurements to geologic field 
conditions realized the importance of determining the effect of confining (overburden) pressure on the permeability of sandstone. The permeability of sandstones appears to be dependent on the mechanical and textural properties of individual samples. From the available data, several factors affecting the permeability of sandstone at simulated confining pressures inciude 1) the magnitude of the confining stress, 2) the initial unconfined permeability of the sandstone, 3) the clay content of the sandstone, 4) the extent of fractures within the sandstone, and 5) the mechanical properties of the sandstone.

Laboratory measurements of the permeability of unconsolidated sand or sands tone under triaxial confining stresses up to $15,000 \mathrm{psi}$ (103 MPa) have been reported for different fluids including air, water, nitrogen, and oil. In general, asymptotic decreases in sandstone permeability occur with increased confining (overburden) pressure under hydrostatic conditions (Fatt and Davis 1952; McLatchie, Hemstock and Young 1958) and in triaxial compression or extension (wyble 1958). Moreover, the experimental data of Gray, Fatt and Bergamini (1963) and Wilhelmi and Somerton (1967) suggest the maximum reduction in sandstone permeability occurs under hydrostatic compression.

Results obtained by Fatt and Davis (1952); McLatchie, Hemstock and Young (1958); and Thomas and ward (1972) suggest most of the permeability reduction occurs between 0 to $3000 \mathrm{psi}$ ( 0 to $20.7 \mathrm{MPa}$ ) overburden pressure. However, the magnitude of the permeability reduction depended on the initial unconfined permeability, clay content, and extent of fractures of each sandstone. For example, Fatt and Davis (1952) reported greater permeability reductions (10 to $40 \%$ ) with increasing hydrostatic pressure (0 to $103 \mathrm{MPa}$ ) for clean sandstones (low clay content) with greater initial unconfined permeabilities. In contrast, shaly (high clay content) sandstones with the lowest initial unconfined permeability exhibited the largest permeability reduction between 6.9 to $34.5 \mathrm{MPa}$ confining pressure (McLatchie, Hemstock and Young 1958). For sandstones with prominent 
fractures, permeability reductions due to overburden pressures of 0 to 41.4 MPa were as high as 95\% (Thomas and Ward 1972).

The mechanical properties of the sandstone under a confining stress also plays a major role in controlling permeability. The mechanical properties of the rock include the compressibility of the bulk rock as well as the pore matrix compressibility. Bulk and pore compressibilities of sandstones are related to the mineralogy and texture of the rock as well as confining stress (Fatt 1958a; Newman 1973). The butk compressibility of sandstones decreases with increased confining stress and becomes nearly constant at stresses of approximately 12,000 psi (83 MPa) for well-sorted sandstones (Fatt 1958a,b). Dobrynin (1962) was able to correlate decreases in permeability with maximum pore compressibilities of sandstones. In general, sandstones with the largest pore compressibilities exhibited the greatest decreases in permeability with increased confining stress.

The importance of internal stresses generated by pore fluids has also been recognized. The net or effective stress acting on a reservoir matrix will be governed by the extent of the external confining stress due to overburden pressure as well as by the internal stress generated by pore fluids. The effective stress is generally defined as the difference between the confining and pore fluid stresses.

The influence of fluid pore pressure on pore compressibility and sandstone permeability was investigated by Zoback and Byerlee (1975). Their results suggest that increasing the pore pressure increased permeability and pore pressure had approximately four times more effect on the permeability of certain sandstones than did confining pressure. Zoback and Byerlee (1975) suggest this behavior may be the result of the differing compressibilities of the pore matrix materials (e.g., clays) relative to the granular framework minerals (e.g., quartz). The effect of confining stress would be small owing to the higher strength of the granular framework that supports the stress. This condition results in minimal 
pore strain. However, the increase of pore pressure would act directiy on the more compressible pore matrix, resulting in greater pore strain and, hence, larger changes in permeability. This type of behavior has also been suggested by Nur et a]. (1980) who reported that the effect of pore pressure on measured permeabilities was greater than the effect of confining stress for sandstones containing significant amounts of clay.

\section{Effect of Temperature}

The mechanisms that control the permeability of sandstones at high temperatures appear to be more complex. In addition to thermomechanical or structural alterations in the rock matrix at high temperature (Somerton 1974; Somerton, Mehta and Dean 1965; Casse 1975), the change in permeabiiity of sandstone with temperature varies depending on the pore fluid. Studies investigating the permeability of sandstones to water (Weinbrandt 1972; Weinbrandt, Ramey and Casse 1975; Casse 1975; Aruna 1976) at constant confining pressure indicate decreases in permeability (greater than $50 \%$ ) occur with increasing temperatures up to $150^{\circ} \mathrm{C}$. Afinogenov (1969) also recorded large decreases (approximately 90\%) in sandstone permeability to $0 i 1$ up to $100^{\circ} \mathrm{C}$. However, Casse (1975) and Aruna (1976) suggest that the nitrogen permeability of sandstone was essentially independent of temperature between $20^{\circ}$ and $150^{\circ} \mathrm{C}$. The differences in behavior between gas and liquid permeabilities suggest that chemical interactions of the pore fluids and rock may also be important factors controlling the permeability of sandstones at high temperature (Danesh, Ehlig-Economides and Ramey 1978; Aruna 1976). Furthermore, another postulated cause for permeability reductions at high temperature is the liberation and consequent migration of fine clay particles within the pore matrix (Sydansk 1980).

The preceding discussion strongly suggests that the permeability of reservoir sandstone may be affected by elevated temperature-stress conditions in geologic environments similar to those anticipated for CAES. However, one important aspect of CAES not addressed in the aforementioned 
studies is the effect of cyclic fluctuations in temperature and pressure that will be characteristic of CAES operations. Secondly, the extent of the permeability alterations is strongly dependent on the physiochemical properties of individual sandstones. For these reasons, the behavior of reservoir sandstones must be measured on site-specific rock samples subjected to the physical conditions relevant to each particular field application. In this study, factors affecting the permeability of Pittsfield reservoir rock (St. Peter sandstone) under the simulated temperature-stress conditions present at the Pittsfield site are addressed. 


\section{CONCLUSIONS}

The vertical permeability of five borehole samples of St. Peter sandstone from the Pittsfield site ranged from 160 to $600 \mathrm{md}$ when measured at $20^{\circ} \mathrm{C}$ and simulated field stress conditions $\left[\mathrm{P}_{\mathrm{e}}=925 \mathrm{psi}(6.4 \mathrm{MPa})\right]$. Four of the samples possess permeabilities greater than the minimal requirement ( $>300 \mathrm{md}$ ) for aquifer-CAES (A1len et al. 1983) under these conditions. However, several samples studied exhibit permeability hysteresis effects that result in cumulative permeability losses during cyclic fluctuations of temperature $\left(20^{\circ}\right.$ to $\left.180^{\circ} \mathrm{C}\right)$ or effective stress $(4.8$ to $46.2 \mathrm{MPa}$ ) conditions characteristic of CAES environments. The amount of cumulative permeability loss varies between 13 to $20 \%$ depending on the temperature-stress conditions. This permeabitity loss is small when compared to the average permeability of the sandstone. Therefore, the permeability loss should not present a significant problem to the development of aquifer-CAES.

Sma 11 changes $(0$ to $5 \%)$ in the permeability of St. Peter sandstone were measured at a constant confining stress of $1200 \mathrm{psi}(8.3 \mathrm{MPa})$ as the pore pressure was varied between 20 and 300 psi $(0.14$ to $2.1 \mathrm{MPa})$. This range of pore pressure is within the expected limits of injection pressures anticipated at the CAES Pittsfield test. Therefore, the permeability of the reservoir rock should not be affected by changes in injection pressures within these limits.

The data for the stress cycling experiments suggest the permeability behavior at $20^{\circ} \mathrm{C}$ is related to the mechanical response of the sandstone matrix. This conclusion is supported by the simultaneous measurements of strain and permeability, which indicate:

- similar strain and permeability behavior during stress loading and unloading

- permeability reduction for all cycles is greatest at low effective stresses where the sandstone matrix is more compressible 
- sample axial strain during all cycles implies the sandstone matrix is more compressible at low confining stress as indicated by the increase in tangent (Young's) modulus with increasing confining stress

- similar hysteresis effects in permeabitity and strain that result in permanent permeability loss

- strain hysteresis is largest in the first cycle and diminishes with further cycling, the result of the transition of the sandstone from inelastic to more elastic behavior

- permeability hysteresis is also largest for the first cycle and decreases with subsequent cycles as the sample behaves more elastically.

Similar conclusions regarding the relationship between the mechanical and temperature-stress behavior of $5 t$. Peter sandstone cannot be accurately deduced because strain measurements were not obtained during the temperature-cycling experiments. The permeability of St. Peter sandstone increased ( 0 to $7 \%$ ) during heating to $180^{\circ} \mathrm{C}$ and then decreased (7 to $15 \%$ ) at a faster rate during cooling to room temperature. Other possible mechanisms that could alter the sandstone permeability with temperature include:

- geochemical alteration of the sandstone by the flowing medium

- liberation and migration of clays at high temperature

- disaggregation of the sandstone matrix causing pore plugging.

Because dry air (<5\% relative humidity) was used as the flowing medium and the samples of St. Peter sandstone studied contained very small amounts of clay, geochemical interactions or clay migration are probably not viable mechanisms for the measured permeability loss in these experiments.

Temperature cycling produced a permeability hysteresis effect similar to the one observed during stress cycling. In both cases, the permeability 
hysteresis is greatest for the first temperature or stress cycle and decreases with subsequent cycling. The similarity of the permeability behavior in the stress and temperature cycling experiments indicates permeability changes at temperature may also be partly controlled by the mechanical behavior of the sandstone. However, internal damage to the sandstone at elevated temperature and stress conditions could have disaggregated fine particles in the matrix that may constrict pore throats. Therefore, the change in permeability with temperature may be the result of the combined effects of temperature and stress. Monitoring the strain behavior of the sandstone during temperature cycling would facilitate the interpretation of these results. 


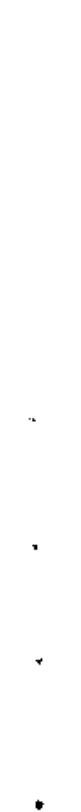




\section{EXPERIMENTAL EQUIPMENT}

The laboratory experiments described in this report were conducted in the CAES Porous Media Flow Loop (PMFL). The PMFL offers the capability of subjecting rock samples to controlled laboratory conditions characteristic of CAES. The process variables that can be controlled include 1) air flow through rock specimens, 2) alternating direction of air flow, 3) inlet air humidity, 4) rock sample and air temperature, 5) triaxial confining stress (pressure), and 6) pore (air) pressure. The ranges of the major process variables that can be controlled are listed in Table 1.

\section{TABLE 1. Porous Media Flow Loop Capabilities}

\section{Control Variable}

Sample temperature

Axial confining load (a)

Radial confining pressure

Pore pressure

In]et air relative humidity (b)

\begin{tabular}{|c|c|}
\hline & \\
\hline English & Metric \\
\hline
\end{tabular}

0 to $250,000 \mathrm{lb} 0$ to $113,400 \mathrm{~kg}$

0 to $10,000 \mathrm{psi} 0$ to $68.9 \mathrm{MPa}$

0 to 5,000 psi 0 to $34.5 \mathrm{MPa}$

0 to $100 \%$

(a) For an $N X(2.125-i n$. dia.) rock sample, maximum axial confining

(b)essure is approximately 70,000 psi
This variable was actually held at $<5 \%$.

A major advantage of the PMFL is that the physical properties of the rock, such as permeability, can be measured at the temperature-pressure conditions of an experiment. In this section, a detailed description of the PMFL is presented. 
APPARATUS DESCRIPTION

The CAES PMFL is a "once-through" flow system in which air flows through a porous rock sample that can be triaxially stressed and heated. The variables measured during this process include 1) sample, inlet air, and outiet air temperatures, 2) axial load on the rock sample, 3) confining pressure on the rock sample, 4) pore pressure, 5) flow rate of air through the rock sample, and 7) inlet and outlet air relative humidities.

A detailed schematic of the PMFL is presented in Figure 1 . The system outlined in Figure $T$ is subdivided into six segments: 1) an air pressure line, 2) a steam pressure line, 3) a two-phase (air/steam) pressure line, 4) a test cell, 5) a hydrautic system for the axial load, and 6) a hydraulic system for the confining pressure.

Test Stand and Hydraulic System

The main part of the system is the test stand comprising a load frame, test cell (pressure vessel), and a load cell. The test cell provides a means of applying a triaxial stress to a rock sample and also to heat rock samples during experimentation. The test cell and load frame are shown in Figure 2.

The test cell is placed into a load frame capable of maintaining a maximum of $250,000 \mathrm{lb}$ load. The test cell is designed for use with NX-sized (2.125-in. diameter) cylindrical rock samples. The pressure vessel is a triaxial cell in which axial and radial pressures imposed on a sample can be separately controlled. The axial and radial pressures are generated using separate high-pressure hydraulic lines and two air-driven hydraulic pumps. For experiments at low confining pressures (<2000 psi), there is also an option of using separate hydraulic accumulators to generate pressure. The pressure medium used in the hydrautic systems is a heat transfer oil, Multitherm $P G-1$.

Load on the rock sample is applied via a ram assembly and is measured using a strain gauge load cell. Radial confining pressure within the

${ }_{A}$ A product of the Multitherm Corp., Colwyn, Pennsylvania 


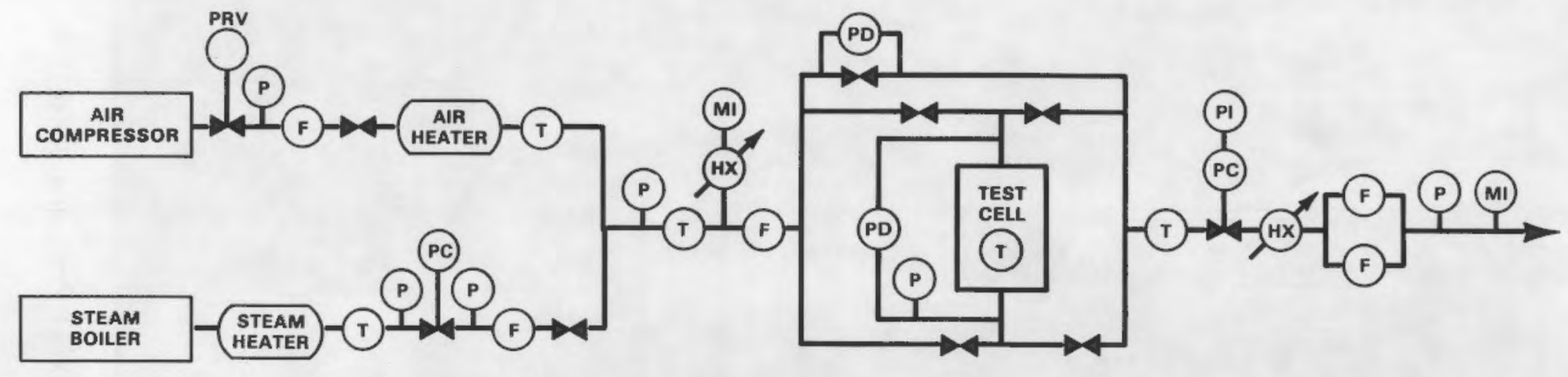

$\vec{\omega}$
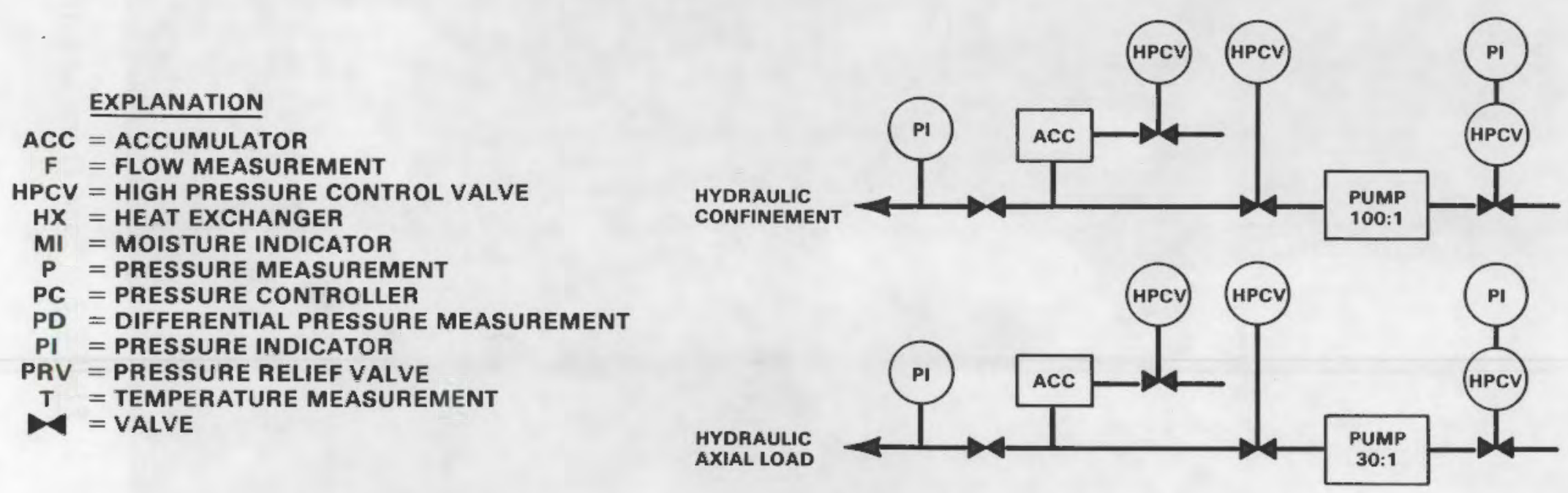


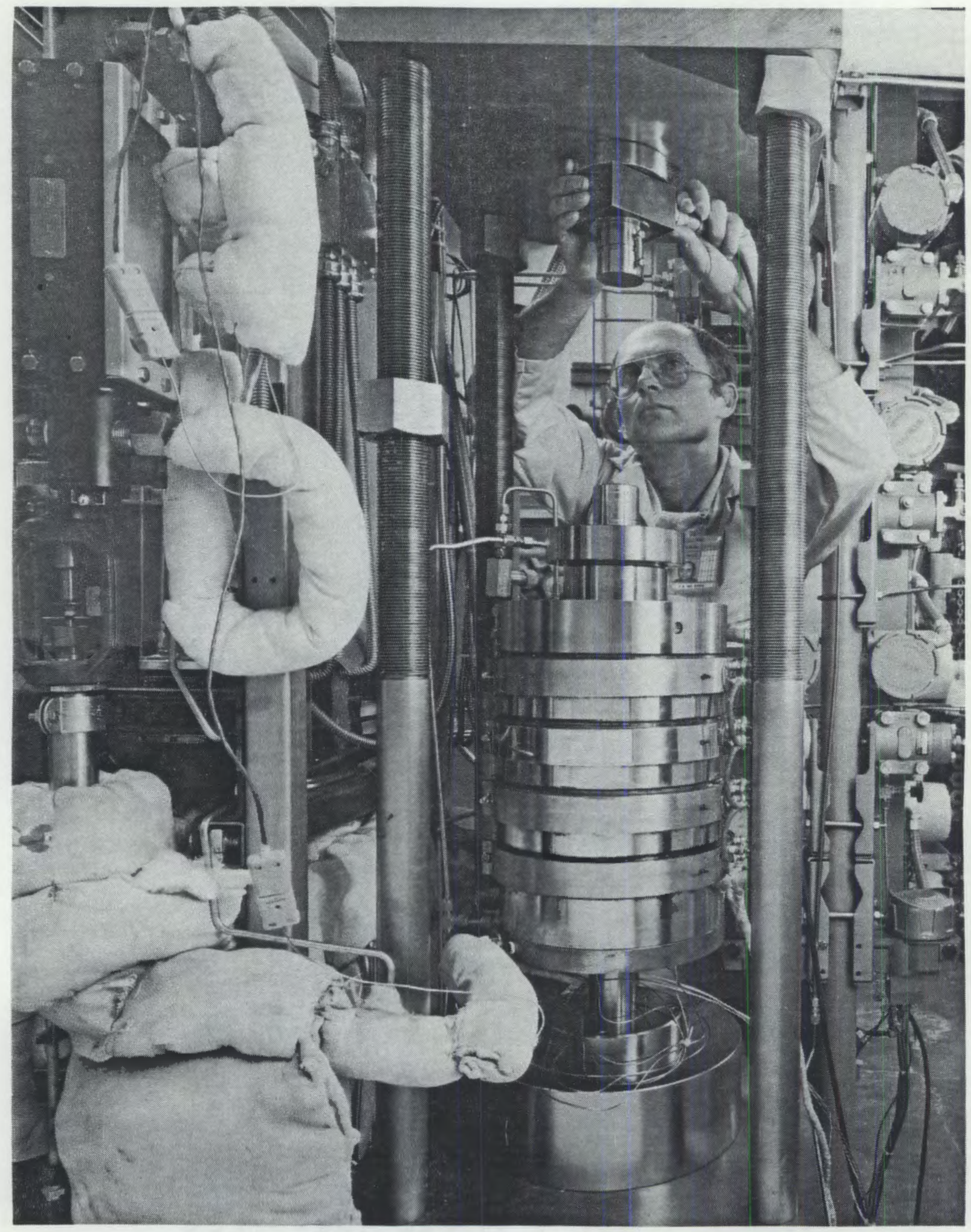

FIGURE 2. Load Frame and Triaxial Pressure Vessel 
pressure vessel is measured using a bourdon tube gauge and a pressure transducer.

There are also provisions inside the test cell for 1) temperature measurement, 2) sample strain measurement, and 3) air flow through the sample. The pressure vessel is externally heated by four band heaters and the temperature of the rock sample is measured using three Type $K$ thermocouples. Axial and radial displacements of the rock sample are measured separately using six linear variable differential transformers (LVDTs). The pressure vessel is also equipped with inlet and outlet pore pressure fittings that allow the continuous flow of air through the sample while the sample is triaxially stressed.

\section{Air/Steam Lines}

The PMFL has two distinct 316 stainless steel pressure lines for air and steam. Air is pressurized by a four-stage air compressor capable of output pressures of 5000 psi ( $34.5 \mathrm{MPa}$ ). Steam, if desired, is generated by a steam boiler. The two phases are mixed, and the mixture flows into the two-phase pressure line, which is connected to the inlet/outlet pore pressure ports of the pressure vessel. To maintain inlet/outlet air temperatures equal to the sample temperature, the two-phase pressure line is trace-heated with resistance windings and insulated. Values of the following important variables are either measured or controlled in this two-phase segment of the pressure line: 1) air flow direction through the sample, 2) pore (air) pressure, 3) volumetric flow rate of air, 4) differential air pressure across the sample, 5) inlet and outlet air relative humidity, and 6) inlet/outlet air temperature.

Five valves located in this portion of the pressure line are situated so flow can either bypass the sample or flow in either direction through the rock sample. Pore (air) pressure is controlled by a bourdon tube pressure controller located downstream of the sample. The volumetric flow rate of air through the sample is also measured at room temperature and pressure downstream of the sample using two turbine flow meters. Both 
flow meters can be valved into or out of the pore pressure line and are used to measure a distinct range of air flow rates. The range of air volume flow rates that can be measured at standard conditions are 1 to 12 $\mathrm{cm}^{3} / \mathrm{sec}$ and 7 to $60 \mathrm{~cm}^{3} / \mathrm{sec}$. Differential air pressure across the sample is measured by two differential pressure transducers. The two ranges of differential pressure measurement are 0 to 20 psi ( 0 to $0.14 \mathrm{MPa}$ ) and 0 to 100 psi ( 0 to $0.69 \mathrm{MPa}$ ). Inlet and outlet air relative humidities are measured using two condensation dewpoint hygrometers that are separated from the pressure line by heat exchangers.

Data Acquisition System

The PMFL is also equipped with a data acquisition system (DAS) that continuously monitors approximately 36 signals from sensors located in the flow loop. The sensor variables monitored from various segments of the loop include 1) temperatures, 2) pressures, 3) differential pressures, 4) air flow rates, 5) LVDT signals, and 6) air humidities. The central components of the DAS are a PDP $11 / 34$ computer, Analogic A/D multiplexer, terminal and CRT, and a line-printer. The DAS allows the operator to monitor the values of all variables simultaneously on the CRT and also enables the user to perform off-line data reduction. A photograph of the PMFL showing the DAS and the front instrumentation panel is presented as Figure 3. 


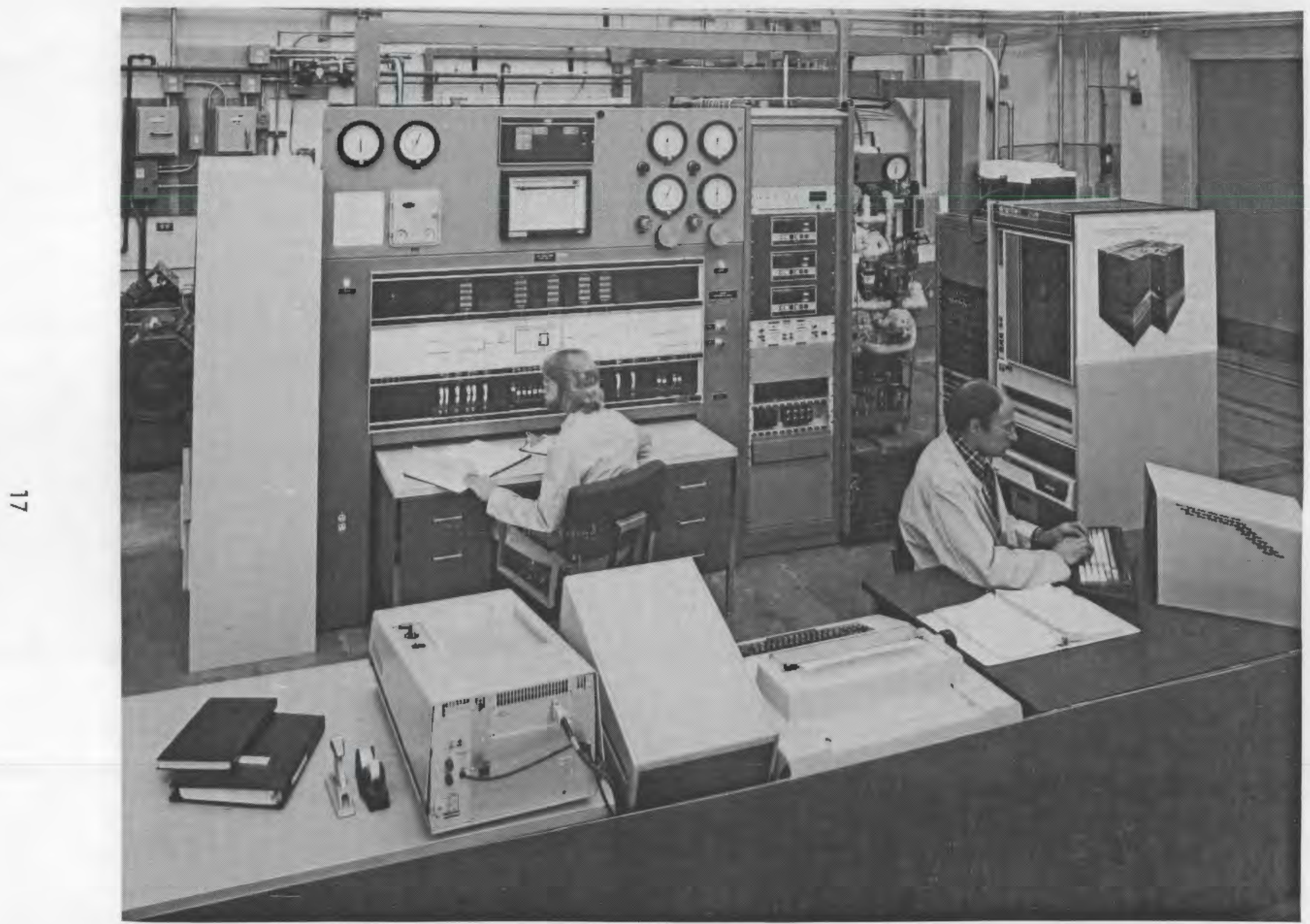

FIGURE 3. Instrumentation Panel and Data Acquisition System for Porous Media Flow Loop 



\section{EXPERIMENTAL PROCEDURE}

The preliminary measurements discussed in this report were designed to determine what parameters affect the vertical permeability of the Pittsfield reservoir rock (St. Peter sandstone). The measurements completed include 1) sandstone permeability at room temperature at simulated overburden pressures, 2) effect of temperature on permeability at constant effective stress, 3) effect of cyclic temperature on permeability, and 4) effect of cyclic effective stress on permeability at constant temperature. The controlled parameters in these experiments include 1) sample and air temperatures $(T), 2)$ confining pressure $\left.\left(P_{c}\right), 3\right)$ pore pressure $\left.\left(P_{p}\right), 4\right)$ inlet air humidity $\left(\phi_{j}\right)$, and 5$)$ air flow rate $(Q)$. Six experiments on five different rock samples have been completed. Table 2 summarizes the run conditions of each experiment.

IABLE 2. Run Conditions for Experiments

\begin{tabular}{|c|c|c|c|c|}
\hline $\begin{array}{l}\text { Experiment } \\
\text { Number }\end{array}$ & $\begin{array}{l}\text { Sample } \\
\text { Number (a) }\end{array}$ & $\mathrm{T}\left({ }^{\circ} \mathrm{C}\right)$ & $P_{c}(p s i)^{(b)}$ & $P_{p}(p s i)$ \\
\hline 1 & 675 & $20-60$ & 1200 & 275 \\
\hline 2 & 655 & $20-90$ & 1200 & 275 \\
\hline 3 & 657 & $20-180$ & 1200 & 275 \\
\hline 4 & 703 & $20-180$ & 1200 & 275 \\
\hline 5 & 703 & 20 & 1200 & $20-300$ \\
\hline 6 & 664 & 20 & $1000-7000$ & 300 \\
\hline
\end{tabular}

(a) SampTe numbers refer to depth from surface (in feet) at the Pittsfield site. (b) Confining stresses were hydrostatic (i.e., $\sigma_{1}=\sigma_{2}=\sigma_{3}$ ) for all
experiments.

The ranges for the controlled independent variables are consistent with the actual conditions expected during the CAES field test (Allen and Doherty 1982). The pore pressures and air temperatures chosen (Table 2) are consistent with the temperatures $\left(50\right.$ to $\left.200^{\circ} \mathrm{C}\right)$ and pressures $(<300$ 
psi) of the air at the field site during injection and operation of the field test. The samples studied were obtained from depths of 650 to $700 \mathrm{ft}$ and the confining stress for most experiments was 1200 psi $(8.3$ $\mathrm{MPa}$ ). This value of confining stress, although slightly large for these shallow depths due only to average lithostatic pressure $(1.0 \mathrm{psi} / \mathrm{ft})$, is still reasonable if one considers what the stress may be when the reservoir volume is heated. The range of reservoir depth considered for the aquifer-CAES technology is 200 to $1500 \mathrm{~m}$ (Allen et a1. 1983). The range of confining stress of Experiment 6 (Table 2) is applicable to CAES if these deeper reservoirs are considered. The data of Gray, Fatt and Bergamini (1963) and Wilhelmi and Somerton (1967) indicate that laboratory measurements of the changes in permeability with triaxial confining stress were a maximum for sandstones under hydrostatic conditions. In all the present experiments, confining stress was hydrostatic and the experimental results probably represent "worst-case" conditions. Volumetric air flow rates used in this laboratory study ranged from 20 to $50 \mathrm{~cm}^{3} / \mathrm{sec}$ (velocity $=0.9$ to $2.2 \mathrm{~cm} / \mathrm{sec}$ ). These flow rates are representative of the rates expected at the sandface of the field-site injection/withdrawal borehole and are in the expected range of sandface velocities for a full-scale CAES system well design.

\section{SAMPLE PREPARATION AND DESCRIPTION}

The samples tested in this study were field borehole samples of St. Peter sandstone from the CAES field demonstration site in Pittsfield, Illinois. The cores received were approximately $4 \mathrm{in}$. in diameter and were of variable lengths. Borehole samples were subsequently reduced in diameter to 2.125-in. (NX) and cut into 4-in. lengths perpendicular to the bedding. The ends were faced and cut parallel to a tolerance of \pm 0.003 in. $( \pm 0.008 \mathrm{~cm})$. Five samples from depths of $655,657,664,675$, and 703 $\mathrm{ft}$ at the Pittsfield site were studied. Hereafter, the samples will be designated with the number indicating the depth (from the surface) of the sample under discussion. 
Before testing, each cylindrical sample was oven-dried at $105^{\circ} \mathrm{C}$ for a minimum of 24 hours and the sample ends cleaned with pressurized dry nitrogen gas. The length and diameter of each sample were also measured using a caliper. Bulk densities $\left(\rho_{B}\right)$ and apparent porosities $\left(\phi_{p}\right)$ were measured on three of the five samples. After oven-drying at $105^{\circ} \mathrm{C}$, each sample was weighed and subsequently saturated under vacuum with distilled water and reweighed. The bulk density and porosity calculated from the core dimensions, wet weight, and dry weight using the saturation and caliper technique of Franklin (1972) are listed in Table 3.

TABLE 3. Bulk Density and Apparent Porosity of Laboratory Samples of St. Peter Sandstone

$\begin{array}{ccc}\text { Sample No. } & \frac{\rho_{\mathrm{B}}(\mathrm{g} / \mathrm{cm})}{{ }^{2}} & \stackrel{\phi_{\mathrm{p}}}{657} \\ 664 & 2.09 & 0.16 \\ 703 & 2.19 & 0.16 \\ & 2.04 & 0.19\end{array}$

Samples of St. Peter sandstone from the Pittsfield site have been previously characterized (PB-KBB Inc. and David K. Davies and Associates 1983). For clarity, however, the characteristics of specific samples used in this study are described below.

The reservoir rock at Pittsfield was subdivided into three zones based on differing textural and mineralogical characteristics. The three zones identified were green, white, and gray St. Peter sandstone. Four of the samples studied $(655,657,664$, and 675) are classified as white St. Peter sandstone. These samples are well-sorted and medium-grained with average grain diameters of 0.37 to $0.45 \mathrm{~mm}$. Quartz is the dominant detrital mineral and the grains are mostly cemented by silica (i.e., syntaxial quartz overgrowths) (Pettijohn, Potter and Siever 1972). The white St. Peter sandstone is texturally mature, containing minor to no detrital clay matrix. 
The fifth sample (703), classified as gray St. Peter sandstone, is also moderately well-sorted and medium-grained. This sample is composed of detrital quartz grains, authigenic clays, and minor iron sulfide. All samples studied are compositionally quartz arenites (Folk 1968).

\section{SAMPLE JACKETING AND ASSEMBLY}

Because the sandstone samples were enclosed in a pressure vessel, it was necessary to isolate the sample and pore fluid (air) from the confining medium (hydraulic oil). This was accomplished by jacketing each sample with RTV silicone rubber and heat-shrink teflon tubing. A schematic representation of a completed sample assembly is depicted in Figure 4. The sample was first placed between upper and lower endcaps that are part of the load ram assembly. Stainless steel plates containing inserts packed with 200 mesh stainless steel screen were then placed between the top and bottom of the sample and each endcap. The porous plates were used to disperse the air flow over the cross-sectional area of the rock sample. Three stainless steel buttons needed for the radial LVDTs were then attached to the sample. The endcap-plate-sample assembly was then coated with two layers of silicone rubber that effectively isolated the sample and pore fluid from the confining medium. After the silicon rubber cured, a tefion sleeve was placed over the sample and shrunk with a heat gun until a snug fit was achieved. The teflon sleeve was then lock-wired to the upper and lower endcaps using nichrome wire.

The deformation jacket needed for the measurement of sample strain was assembled next. A completed deformation jacket assembly is illustrated in Figure 5 . This deformation jacket consists of three circular stainless steel plates placed around the sample-endcap assembly and used to support the six LVDTs. The bottom and top plates were clamped tightly onto the lower and upper endcaps, respectively. The middle plate was aligned with respect to the center of the sample and was supported by three vertical spacer posts that screw into the bottom plate. The LVDTs used for radial and axial displacement measurements were placed in holes 


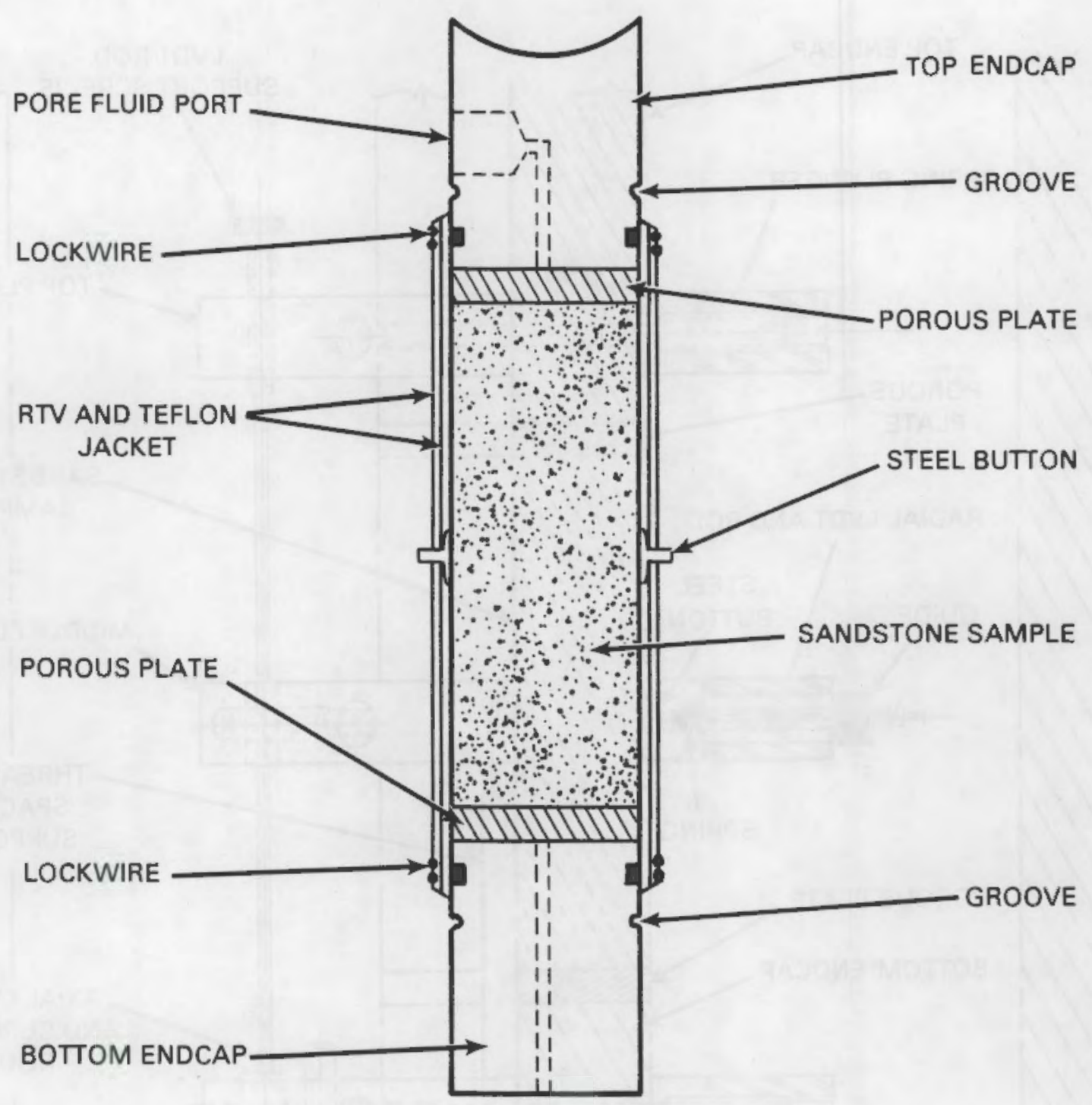

FIGURE 4. Sample Assembly Schematic 


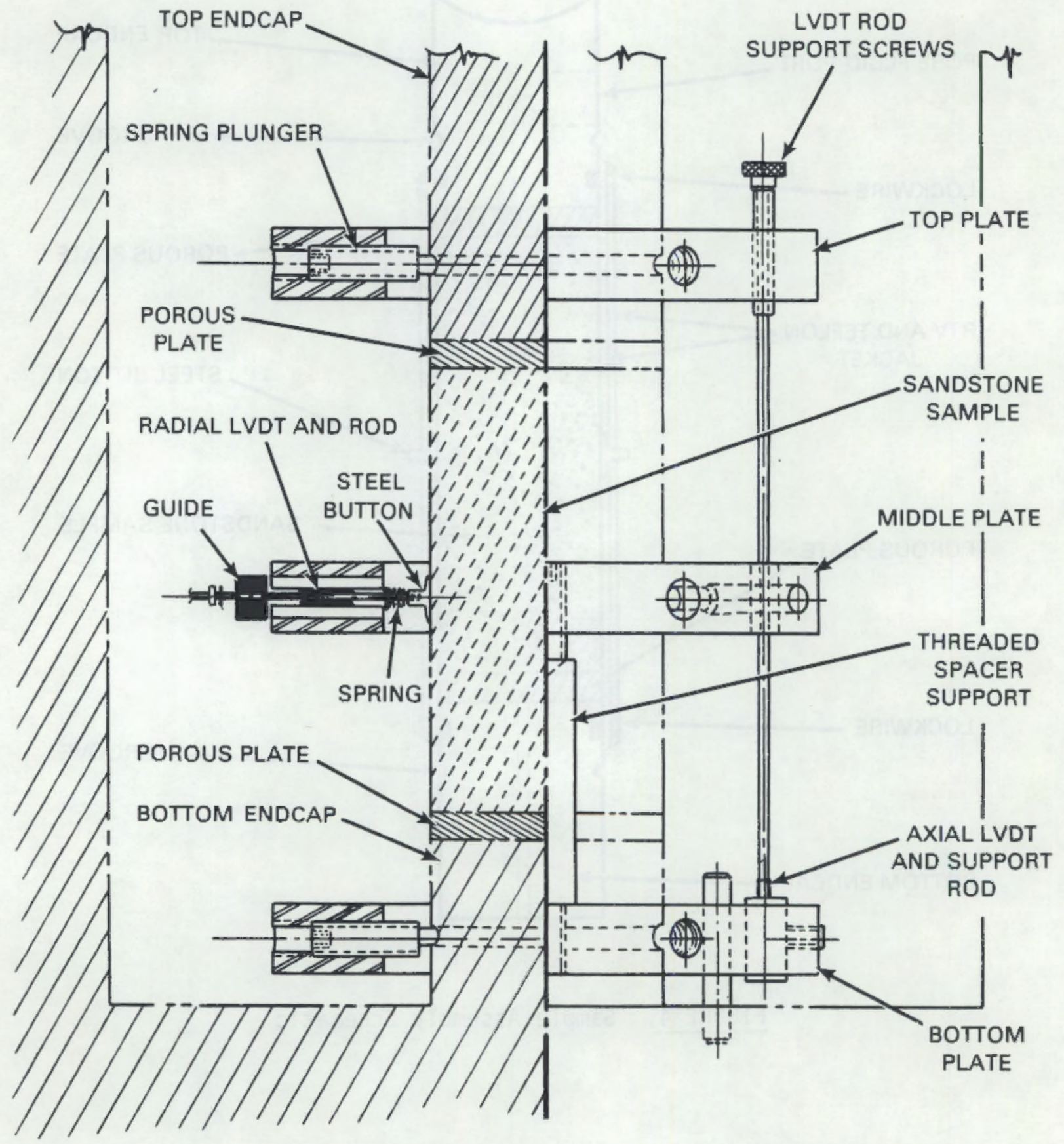

FIGURE 5. Deformation Jacket Assembly Schematic 
drilled through the middle and bottom plates, respectively, and clamped into position using set screws. Cores for each LVDT were threaded onto rods that pass through the center of the LVDT. Each threaded rod was adjusted so that the core rested inside the LVDT and the initial position of the core was fixed. This was accomplished for the radial LVDTs by maintaining tension between the LVDT core rod and the steel button using sma11 springs. For each axial LVDT, the core position was fixed by threading each rod into the top plate.

\section{PERMEABILITY/TRANSIENT TEMPERATURE EXPERIMENTS}

Experimental difficulties precluded obtaining data for long periods of time in Experiments 1 and 2 (TabTe 2), as each experiment ended prematurely. Therefore, only a limited amount of data was obtained. In each of these experiments, the samples were first hydrostatically loaded to a confining pressure $\left(\mathrm{P}_{\mathrm{c}}\right)$ of $1200 \mathrm{psi}(8.3 \mathrm{MPa})$. The pore pressure was gradually increased and controlled at $275 \mathrm{psi}(1.9 \mathrm{MPa})$ before flow was initiated. Permeabilities were measured at $20^{\circ} \mathrm{C}$ for several hours, and the samples were then heated at approximately $0.5^{\circ} \mathrm{C} / \mathrm{min}$. During the temperature transient, values for flow rate $(Q)$ and differential pressure $(\triangle P)$ across the sample were continuously logged by the DAS. Permeabilities were then calculated during the temperature transients over a specific time interval. Both experiments ended prematurely due to fitting leaks; Experiment 1 was terminated at $60^{\circ} \mathrm{C}$ and Experiment 2 at $90^{\circ} \mathrm{C}$.

\section{PERMEABILITY/TEMPERATURE CYCLING EXPERIMENTS}

Experiments 3 and 4 (Table 2) were designed to determine the effects of temperature cycling on the permeability of St. Peter sandstone. For these experiments, each sample was hydrostatically pressurized to $\mathrm{P}_{\mathrm{c}}=$ $1200 \mathrm{psi}(8.3 \mathrm{MPa}$ ) and the pore pressure increased to $275 \mathrm{psi}(1.9 \mathrm{MPa}$ ). Permeabilities were first measured as a function of time at room temperature. Each sample was subsequently heated at approximately $0.5^{\circ} \mathrm{C} / \mathrm{min}$ to discrete temperatures between 20 and $180^{\circ} \mathrm{C}$ and the steady-state permeabil- 
ity measured. At each isotherm, the sample was allowed to equilibrate for a minimum of 2 hours. During the temperature traverses, the inlet air temperatures were controlled to match the temperature of the sample and the confining pressure was maintained at $1200 \mathrm{psi}(8.3 \mathrm{MPa})$. After data were recorded at the highest temperature, the samples were cooled at the same rate over approximately the same temperature intervais. Permeability data were recorded over several hours after the sample temperature reequilibrated. The confining pressure $\left(P_{C}\right)$ during the cooling cycle was maintained by occasionaliy adjusting the vessel pressure. For Experiment 3 , one temperature cycle was completed; three temperature cycles were completed for Experiment 4.

\section{PERMEABILITY/PORE PRESSURE EXPERIMENT}

The effect of pore pressure (at constant confining pressure) on permeability was determined at $20^{\circ} \mathrm{C}$ in Experiment 5 (Table 2). Sample 703 was hydrostatically confined at $P_{C}=1200 \mathrm{psi}(8.3 \mathrm{MPa})$ and the pore pressure varied between 20 and 300 psi $(0.14$ and $2.1 \mathrm{MPa})$ in discrete intervals. Permeabilities were measured after the pore pressure and flow rate had reached steady-state values.

\section{PERMEABILITY/STRESS CYCLING EXPERIMENT}

The effect of stress on the permeability of the reservoir sandstone was determined in Experiment 6 (Table 2). In this experiment, permeabi1ities were measured at $20^{\circ} \mathrm{C}$ and a constant pore pressure of 300 psi (2.l $\mathrm{MPa})$. The hydrostatic confining stress, however, was varied between 1000 and $7000 \mathrm{psi}(6.9$ and $48.3 \mathrm{MPa})$. Therefore, the range of effective stress $\left(P_{c}-P_{p}\right)$ for this experiment varied between 700 and 6700 psi $(4.8$ and 46.2 $\mathrm{MPa})$. At each isobar, permeability measurements were recorded over several hours. For each loading cycle, confining stress was increased in 1000-psi increments between 1000 and $7000 \mathrm{psi}$. Data were obtained for only the 5000-, 3000-, 2000-, and 1000-psi isobars on the unloading cycle. 
Three loading-unloading cycles were completed for this experiment. Axial sample strain was measured simultaneously with permeability as a function of effective stress during the loading-unloading cycles.

\section{METHODS OF CALCULATION}

The primary dependent variables measured in the experiments of the present study include 1) permeability of the rock to air, 2) relative and specific humidity of the pore air, and 3) axial strain of the rock sample. In this section, the methods used to calculate these variables are described. The methods outlined were incorporated into a general computer program written for the DAS, which allowed the calculation of values for each of these variables for a given set of run conditions.

\section{Permeability}

The permeability of the reservoir rock for a given set of run conditions was calculated using a form of Darcy's Law for a compressible gas:

$$
K=\frac{\tilde{V}_{P, I}}{\tilde{V}_{0}} \frac{\mu Q L}{A \Delta P}
$$

where $K$ = apparent permeability, darcy

$$
\begin{aligned}
\mu= & \text { gas viscosity at flow temperature, } c P \\
Q= & \text { gas flow rate at pressure-temperature conditions of turbine } \\
& \text { flowmeter, } \mathrm{cm}^{3} / \mathrm{sec} \\
\mathrm{L}= & \text { sample length, } \mathrm{cm} \\
A= & \text { sample cross-sectional area, } \mathrm{cm}^{2} \\
\Delta P= & \text { differential pressure across sample, atm (absolute) } \\
\tilde{V}_{P, T}= & \text { specific volume of air at flow pressure-temperature } \\
& \text { conditions at sample, } \mathrm{cm}^{3} / \mathrm{g} \\
\tilde{V}_{0}= & \text { specific volume of air at flow pressure-temperature } \\
& \text { conditions at reference point, } \mathrm{cm}^{3} / \mathrm{g}
\end{aligned}
$$

The flow rate is measured at a reference point downstream of the sample by turbine flowmeters that are at standard temperature and pressure. 
However, a volumetric (density) correction for a compressible gas must be applied to account for differences in the $P-V-T$ properties of air at the sample flow conditions relative to the flowmeter reference point. The vaiue of $\tilde{V}_{P, T}$ was evaluated at the temperature and mean gas pressure conditions at the sample. The mean gas pressure was calculated from the measured values of $\triangle P$ and downstream pressure during an experiment. The permeability values reported in this study were not corrected for $\mathrm{K} 1$ inkenberg effects ( $\mathrm{K}$ linkenberg 1941) and are referred to as apparent permeabilities. However, the magnitude of the $\mathrm{Kl}$ inkenberg correction at the pore pressures used in this study ( 300 psi) would probably be small. For a demonstration of $\mathrm{kl}$ inkenberg effects on the gas permeability of sandstones the reader is referred to the data of Casse (1975) and Aruna (1976).

The P-V-T properties of air used in the calculations were obtained from Crane Co. (1965). Air viscosity data, corrected for temperature, were obtained from weast (1971). The effect of pressure on air viscosity over the working pore pressures $[20$ to $300 \mathrm{psi}(0.14$ to $2.07 \mathrm{MPa})]$ used in this study was small enough to be ignored. The dimensions of each sample $(L, A)$ were measured to an accuracy of $\pm 0.003 \mathrm{in.}( \pm 0.008 \mathrm{~cm})$ using a caliper, and vatues of $Q$ and $\triangle P$ were measured using a turbine flowineter and differential pressure transducer, respectively. The accuracy of the flow and differential pressure measurements is \pm 0.20 and $\pm 0.25 \%$, respectively.

The run conditions under which permeability was measured were slightly different depending on the experiment. In Experiments 1 and 2 described in a previous section, permeability was measured during a temperature transient. Permeabilities were calculated from the raw data in 3-minute intervals as the sample was heated. However, in Experiments 3 through 6 , permeabilities were measured over several hours after the confining stress, pore pressure, temperature, and flow rate had reached steady-state values. In this case, permeabilities were calculated in 5-minute intervals under the steady-state conditions. For any given set of run conditions in Experiments 3 through 6 , a minimum of 25 permeability 
measurements was recorded and averaged. Thus, permeabilities measured in Experiments 3 through 6 are reported as the average permeability plus or minus one standard deviation $\left(\bar{K}_{ \pm \sigma}\right)$ of the measurements.

Humidity

The humidity of the inlet air flowing through the rock sample can be controlled in the CAES PMFL. This design was incorporated into the PMFL to simulate actual field conditions because air injected into an aquifer reservoir may have a variable water vapor content. Moreover, if dry air were injected into an aquifer saturated with ground water, the humidity of the air will increase during the stages of air bubble development and withdrawn air will be moist.

The humidities of the inlet and outlet air flowing through the rock sample were measured at a reference state using two condensation dewpoint hygrometers that continuously monitor the dewpoint temperature of the mixture. The hygrometers are capable of measuring dewpoints to $\pm 0.40^{\circ} \mathrm{F}$ $\left(0.22^{\circ} \mathrm{C}\right)$ under optimal conditions. The procedure for calculating relative and specific humidities requires several steps.

First, the humidity of the mixture is calculated at the reference state pressure $\left(P_{0}\right)$ - temperature $\left(T_{0}\right)$ conditions of the hygrometers. Because the humidity at the hygrometers is measured near standard temperature and elevated pressure, the humidity of the mixture at the sample flow conditions must be calculated at the elevated pressure $\left(P_{1}\right)$ - temperature $\left(T_{1}\right)$ conditions of the mixture flowing through the sample. At the reference state conditions of the hygrometers, and assuming the mixture is a perfect gas, the relative humidity was calculated using the relationship (Hatsopoulos and Keenan 1965)

$$
\phi_{0}=\frac{P_{s, 0}}{P_{g, 0}}
$$


where $\phi_{0}=$ relative humidity at reference state conditions

$$
\begin{aligned}
\mathrm{P}_{\mathrm{s}, 0}= & \text { vapor pressure of water at the reference state dewpoint } \\
& \text { temperature } \\
\mathrm{P}_{\mathrm{g}, 0}= & \text { saturated vapor pressure of water at the reference state } \\
& \text { temperature }\left(\mathrm{T}_{0}\right) \text { of the mixture }
\end{aligned}
$$

The specific humidity, defined as the mass ratio of water vapor to air in a given volume of mixture, is then calculated at the reference state hygrometer conditions using the relationship (Hatsopoulos and Keenan 1965)

$$
\omega_{0}=\frac{0.662 p_{s, 0}}{p_{a, 0}}
$$

where $\omega_{0}=$ specific humidity at reference state conditions

$$
\begin{aligned}
\mathrm{P}_{s, 0}= & \text { vapor pressure of water at the reference state dewpoint } \\
& \text { temperature } \\
\mathrm{P}_{\mathrm{a}, 0}= & \text { partial pressure of air at the reference state conditions. }
\end{aligned}
$$

Assuming the mixture obeys the Gibbs-Dalton law where $P_{T}$ equals the total pressure of the mixture (equal to the sum of the partial pressures of air and water vapor), Equation (3) then becomes

$$
\omega_{0}=\frac{0.662 P_{S, 0}}{P_{T, 0}-P_{S, 0}}
$$

where $\mathrm{P}_{\mathrm{T}, 0}$ is the total pressure of the mixture at the reference state conditions. The reference state total pressure $\left(\mathrm{p}_{T, 0}\right)$ during ali experiments was essentially 1 atmosphere. The conditions of the mixture at the sample flow conditions in all experiments were at some elevated pore pressure $\left(P_{1}\right)$ and/or temperature $\left(T_{1}\right)$ relative to the conditions at the hygrometers $\left(P_{0}, T_{0}\right)$. To calculate the relative humidity of the mixture at the sample flow conditions, the specific humidity at the sample flow conditions $\left(\omega_{1}\right)$ and at the hygrometers $\left(\omega_{0}\right)$ should be equal $\left(\omega_{0}=\omega_{1}\right)$ if no leaks or condensation occurred in the pressure lines. Based on this assumption, the relative humidity at the sample flow conditions can be 
evaluated if values of the water vapor pressure of the mixture $\left(p_{s, 1}\right)$ and saturated water vapor pressure $\left(p_{g, l}\right)$ are known at the elevated pressure $\left(P_{1}\right)$ and temperature $\left(T_{1}\right)$. Values for $P_{S, l}$ can be calculated by rearranging Equation (4):

$$
\mathrm{P}_{\mathrm{S}, 1}=\frac{\omega_{0} \mathrm{P}_{\mathrm{T}, 1}}{0.662+\omega_{0}}
$$

$$
\text { where } \begin{aligned}
\mathrm{P}_{\mathrm{S}, 1}= & \text { vapor pressure of water in mixture at sample flow } \\
& \text { conditions } \\
\omega_{0}= & \text { specific humidity at reference state conditions }\left(=\omega_{1}\right) \\
\mathrm{P}_{\mathrm{T}, 1}= & \text { total pressure of mixture at sample flow conditions (i.e., } \\
& \text { pore pressure). }
\end{aligned}
$$

The relative humidity $\left(\phi_{1}\right)$ of the mixture at the elevated temperature $\left(T_{7}\right)$ and pressure $\left(P_{1}\right)$ flow conditions can then be calculated using

$$
\phi_{1}=\frac{P_{s, 1}}{P_{g, 1}}
$$

where $\mathrm{P}_{g, l}$ is the saturated vapor pressure of water at the elevated temperature $\left(T_{1}\right)$ of the mixture.

The calculations outlined in Equations (5) and (6) are equivalent to extrapolating the dewpoint temperature to higher total gas pressures. Although data on the dewpoint temperature as a function of pressure are available, the method outlined above was determined to be the easier one for adapting these calculations for computer automation. Values for the vapor pressures of water as a function of temperature used in these calculations were obtained from Keenan et a1. (1978). All the preliminary experiments of the present study were conducted using dry air. Therefore, relative humidities calculated at the flow conditions for all experiments were less than $5 \%$.

\section{Sample Strain}

In Experiment 6 (sample 664), the permeability of the sample was measured as a function of confining pressure at a constant pore pressure 
and temperature of $300 \mathrm{psi}(2.07 \mathrm{MPa})$ and $20^{\circ} \mathrm{C}$, respectively. The axial strain of this sample was a]so measured at each isobar of this experiment using LVDTs in a manner described in a previous section of this report. Radial displacement measurements had been attempted in previous experiments. However, it was found that the steel buttons used to attach the radia? LVDTs to the rock sample developed fluid pressure leaks over several months. Therefore, in Experiment 6 , the use of these buttons was abandoned and only axial displacements were obtained.

The axial strain of sample 664 in this experiment was measured under the conditions of hydrostatic $\left(\sigma_{1}=\sigma_{2}=\sigma_{3}\right)$ compression in the range of 1000 to $700 \mathrm{D}$ psi $(6.9$ to $48.3 \mathrm{MPa})$. The sample strain was calculated from the relationship

$$
\epsilon_{m}=\epsilon_{s}+\varepsilon_{s y s}
$$

where $\quad \epsilon_{m}=$ measured strain as determined from displacement measurements

$$
\begin{aligned}
E_{S} & =\text { unknown sample strain } \\
E_{\text {sys }} & =\text { system strain. }
\end{aligned}
$$

The sign convention adopted for these calculations defines a compressive strain as positive $(+)$ (Jaeger and Cook 1976). The measured strain $\left(\varepsilon_{m}\right)$ is determined from the displacements measured by the LVDTs $(\Delta L)$ and the initial length of the sample $\left(L_{0}\right)$ in that $E_{m}=\left(\Delta L / L_{0}\right)_{m}$. In the calculation of $\varepsilon_{m}$, the average of the axial displacements measured by the three LVDTs was used to calculate measured strain.

The value for $E_{\text {sys }}$ incorporates the strain of the components of the measuring system, which includes LVDTs, endcaps, and the plate assembly (Figure 5). The system strain was characterized by obtaining $\varepsilon_{\mathrm{m}}$ values for a standard sample of well-known elastic properties. The standard sample used in the present study was a 2.125-in. diameter $\times 4$-in.-long cylinder of Al 6061-T6. Data for the elastic properties of this material were obtained from Higdon et al. (1976). Values of $\varepsilon_{s}$ for the aluminum 
alloy under the hydrostatic conditions of the calibration were calculated from its elastic properties and $\varepsilon_{\text {sys }}$ was evaluated using Equation (7).

The system strain calibration was conducted under precisely the same temperature-stress conditions as was Experiment 6 . Measurements of $\varepsilon_{\mathrm{m}}$ were recorded for three loading-unloading cycles over the confining stress range of 1000 to $7000 \mathrm{psi}(6.9$ to $48.3 \mathrm{MPa})$. The stress reference state for zero strain in this study was chosen to be 1000 psi (6.9 MPa) rather than the usual 1 bar $(0.1 \mathrm{MPa})$ for several reasons. First, the lowest confining stress in which permeability was measured was 1000 psi and, for convenience, changes in permeability with increasing confining stress were compared to the initial permeability at 1000-psi confining stress. Therefore, to quantitatively compare permeability and sample strain, it was necessary to aiso choose the same reference state for the strain measurements. Second, displacements measured at very low confining stresses were difficult to measure accurately due to the sensitivity of the LVDTs to their environmental surroundings (e.g., vibration, movement of the pressure vessel and strain measuring system). This problem was eliminated by choosing a reference state at an elevated confining stress.

The response of the system strain $\left(\varepsilon_{\text {sys }}\right)$ to confining stress in all three loading cycles was linear. The agreement between loading and unloading curves in the 1000- to 5000-psi (6.9- to 34.5-MPa) confining stress range was also good. However, there is an inconsistency in the unloading curves between 5000 to $7000 \mathrm{psi}(34.5$ to $48.3 \mathrm{MPa}$ ). In this range of stress conditions, for unknown reasons, the strain measuring system became bound and measured strains obtained during unloading did not reproduce the values measured during loading. The maximum deviation between measured displacements for the loading and unloading curves, 9.59 $\times 10^{-4} \mathrm{in} .\left(2.43 \times 10^{-3} \mathrm{~cm}\right)$, occurred at the 6000-psi isobar. Moreover, this behavior was reproducible in all three unloading cycles. Because this behavior was reproducible, it is assumed that it also occurs during strain measurements on an unknown sample and, therefore, was taken into account in subsequent strain calculations. 
The output voltages for each of the axial LVDTs can be resolved to the nearest $0.001 \mathrm{~V}$, which corresponds to an average measured axial displacement of $1.76 \times 10^{-5} \mathrm{in} .\left(4.46 \times 10^{-5} \mathrm{~cm}\right)$. In the evaluation of $\varepsilon_{\text {meas }}$ for the aluminum standard, the reproducibility of the displacement measurements at any isobar for the three loading-unloading cycles was excellent. For the entire confining stress range of 1000 to 7000 psi $(6.9$ to $48.3 \mathrm{MPa}$ ), measurements were reproducible to an average value of $1.08 \times$ $10^{-4}$ in. $\left(2.74 \times 10^{-4} \mathrm{~cm}\right)$. 


\section{RESULTS AND DISCUSSION}

The results of this study are presented in a series of figures in which the permeability of St. Peter sandstone is shown to be dependent on temperature and effective stress conditions characteristic of CAES. Permeabilities were measured for five samples of St. Peter sandstone over temperatures ranging from $20^{\circ} \mathrm{C}$ to $180^{\circ} \mathrm{C}$, confining pressures between 1000 to $7000 \mathrm{psi}(6.9$ to $48.3 \mathrm{MPa})$, and pore pressures to $300 \mathrm{psi}(2.1 \mathrm{MPa})$.

From the permeability data, permeability ratios $\left(K / K_{0}\right)$ were also calculated. The permeability ratio is here defined as the ratio of permeability at an elevated temperature and/or stress condition ( $K$ ) to the initial permeability at the beginning of each experiment $\left(K_{0}\right)$. For Experiments 1 through $5, K_{0}$ is the initial permeability measured at $20^{\circ} \mathrm{C}$ and $1200 \mathrm{psi}(8.3 \mathrm{MPa})$. The effective pressures used in this study were calculated using the "conventional" stress law in which effective pressure $\left(P_{e}\right)$ equals the difference between confining pressure $\left(P_{c}\right)$ and pore pressure $\left(P_{p}\right)$. Other effective stress formulations have been proposed that describe fluid flow through cracks and pores of varying geometry in rock with respect to combinations of confining and pore pressures (Fatt 1958a; Garg and Nur 1973; Walsh 1981). These were not adopted in this work.

\section{EFFECT OF TEMPERATURE}

The effect of temperature and temperature cycling under CAES conditions anticipated at the Pittsfield field site was studied for four samples of St. Peter sandstone. The data for Experiments 1 through 4 are depicted in Figures 6 through 8. Al1 four experiments were conducted at a constant overburden pressure of $1200 \mathrm{psi}(8.3 \mathrm{MPa})$ and pore pressure of 275 psi (1.9 MPa).

Initial permeabilities of samples $675,655,657$, and 703 measured at ambient temperature $\left(20^{\circ} \mathrm{C}\right)$ and simulated Pittsfield overburden pressure (1200 psi) were approximately $300,480,160$, and $600 \mathrm{md}$, respectively. 


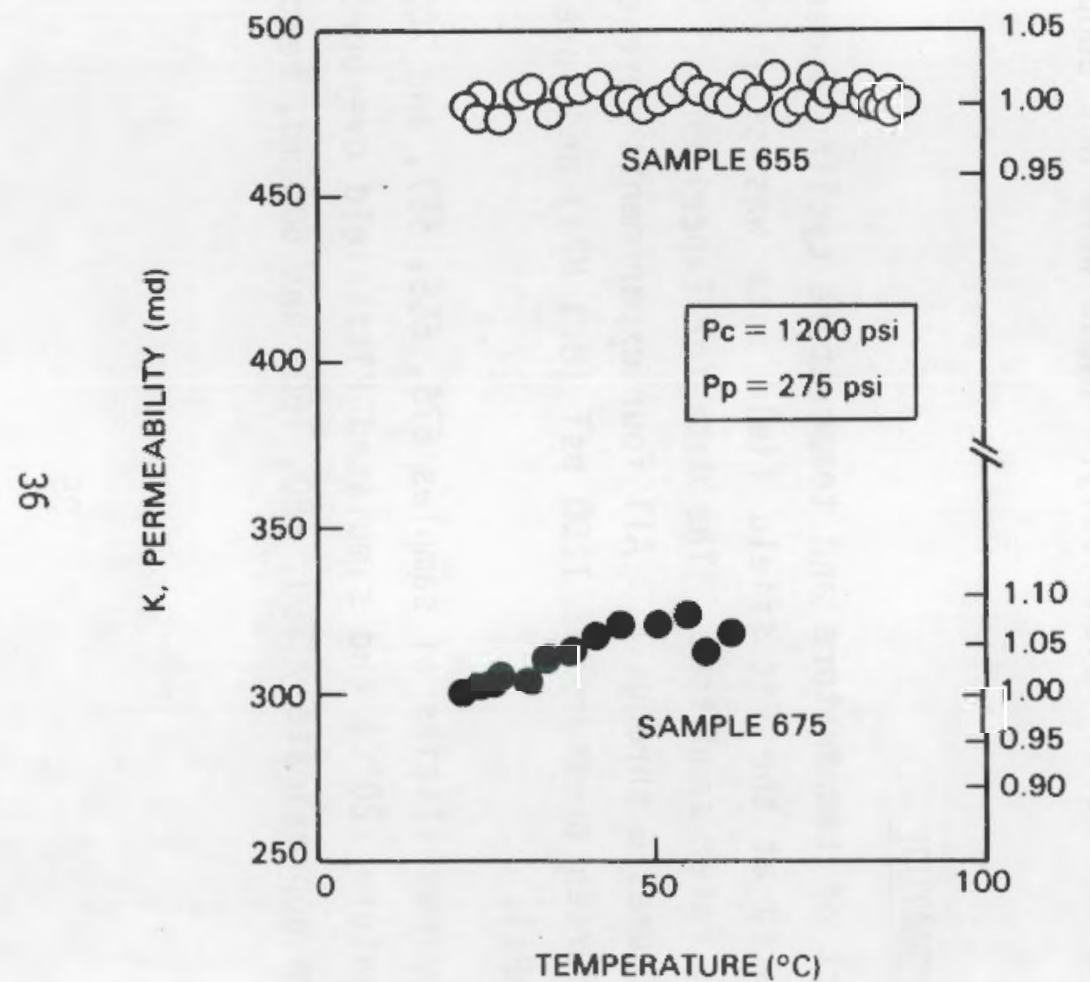

FIGURE 6. Permeability Versus Transient Temperature

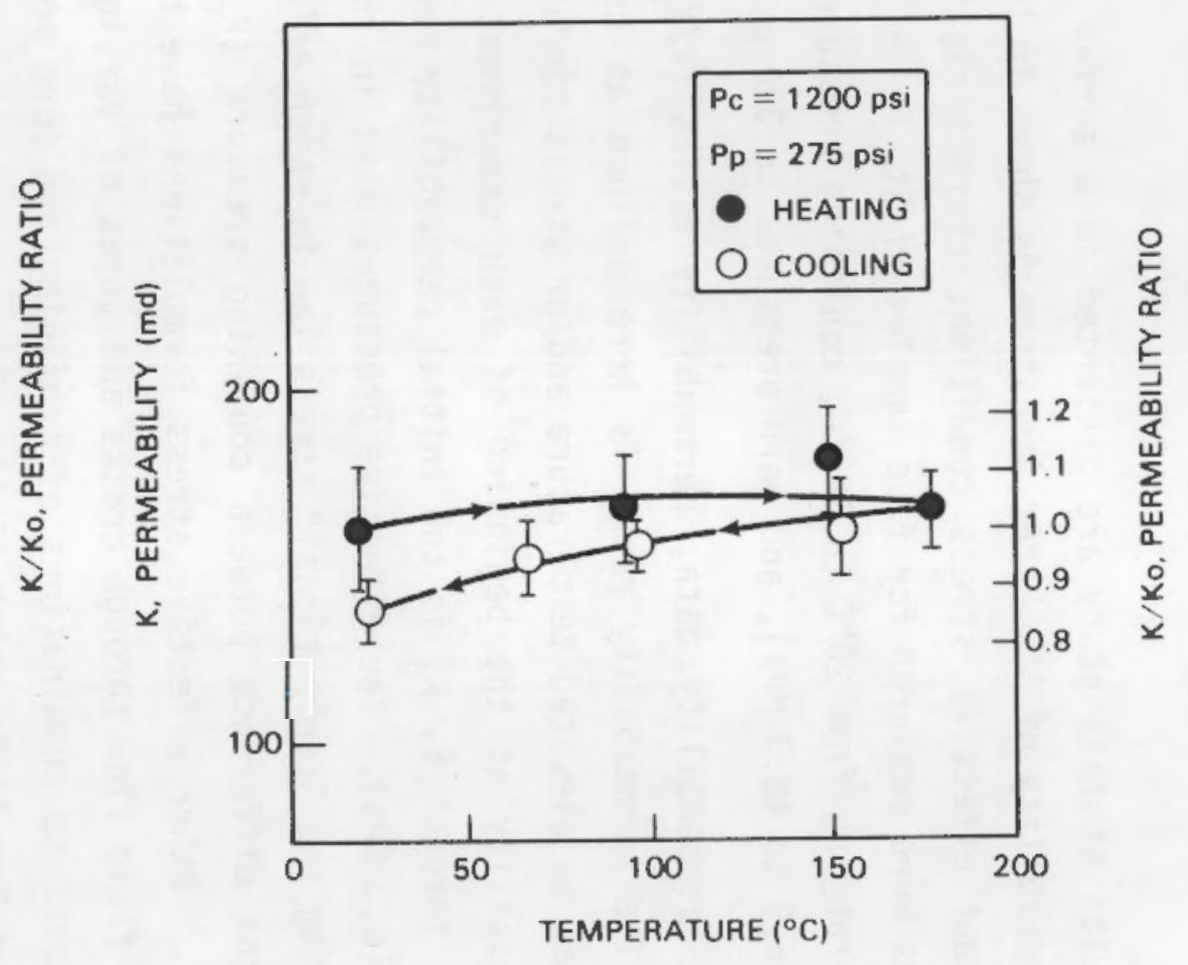

FIGURE 7. Permeability Versus Temperature for Sample 657 


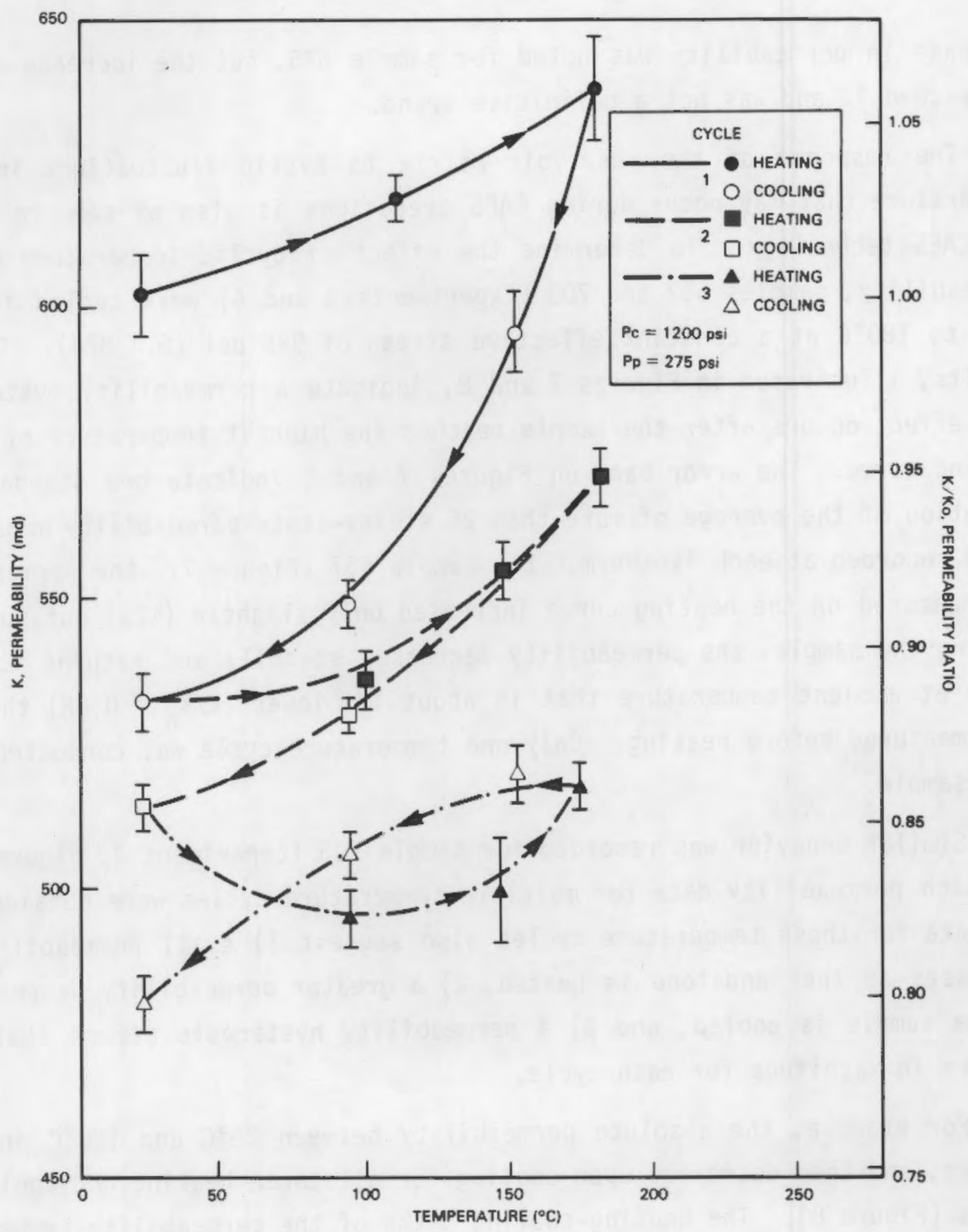

FIGURE 8. Permeability Versus Cyclic Temperature for Sample 703

The results of Experiments 1 and 2 (Figure 6) suggest small changes in sample permeability to dry air during temperature transients between $20^{\circ} \mathrm{C}$ and $60^{\circ}$ or $90^{\circ} \mathrm{C}$. The change in permeability with temperature for sample 655 was essentially independent of temperature up to $90^{\circ} \mathrm{C}$. A small 
increase in permeability was noted for sample 675 , but the increase did not exceed $7 \%$ and was not a definitive trend.

The response of the reservoir matrix to cyclic fluctuations in temperature that may occur during CAES operations is also of concern to the CAES technology. To determine the effect of cyclic temperature on permeability, samples 657 and 703 (Experiments 3 and 4) were cycled from $20^{\circ} \mathrm{C}$ to $180^{\circ} \mathrm{C}$ at a constant effective stress of 925 psi $(6.4 \mathrm{MPa})$. The results, illustrated in Figures 7 and 8 , indicate a permeability hysteresis effect occurs after the sample reaches the highest temperature of the heating curve. The error bars on Figures 7 and 8 indicate one standard deviation of the average of more than 25 steady-state permeability measurements recorded at each isotherm. For sample 657 (Figure 7), the permeability measured on the heating curve increased only slightly ( $2 \%)$ but, upon cooling the sample, the permeability decreases steadily and returns to a value at ambient temperature that is about $12 \%$ lower $\left(K / K_{0}=0.88\right)$ than that measured before heating. Only one temperature cycle was conducted on this sample.

Similar behavior was recorded for sample 703 (Experiment 4, Figure 8) in which permeability data for multiple temperature cycles were obtained. The data for these temperature cycles also suggest 1) small permeability increases as the sandstone is heated, 2) a greater permeability decrease as the sample is cooled, and 3) a permeability hysteresis effect that changes in magnitude for each cycle.

For example, the absolute permeability between $20^{\circ} \mathrm{C}$ and $180^{\circ} \mathrm{C}$ increases, and then decreases upon cooling for all three heating and cooling curves (Figure 8 ). The heating-cooling paths of the permeability-temperature curves for cycles 1 and 2 are quite similar. The path for cycle 3 indicates a permeability minimum and maximum in the heating and cooling curves, respectively. This difference in behavior as compared with cycles 1 and 2 is, at present, not understood. 
The permeability hysteresis effect occurred for all temperature cycles during Experiment 4 (sample 703, Figure 8). The magnitude of the permeability hysteresis was greatest for the first cycle where the sample lost $12 \%$ of its initial permeability $\left(K / K_{0}=0.88\right)$ and was considerably less for the two subsequent cycles. After three complete cycles, sample 703 lost approximately $20 \%$ of its initial permeability $\left(K / K_{0}=0.80\right)$. After one complete temperature cycle, samples 657 and 703 show the same permeability reduction $\left(K / K_{0}=0.88\right)$ under the same effective stress conditions, even though their initial permeabilities are considerably different. Without further experiments on a larger number of samples, it is difficult to discern whether or not this observation is fortuitous.

The permeability reduction in the low effective stress range of these temperature-permeability experiments was small although up to a $20 \%$ cumulative decrease occurred with temperature cycling. However, even after three temperature cycles, the permeability of sample 703 was still 480 md (Figure 8). Unless the permeability continues to decline with an increasing number of cycles, the overall effect on CAES reservoir performance is probably insignificant.

The changes in permeability with temperature measured in this study are similar to data reported in the literature. Casse (1975) and Aruna (1976) measured the temperature effect on nitrogen permeability of Bandera, Berea, and Massillon sandstones at 2000 psi (13.8 MPa) confining pressure by heating samples to $150^{\circ} \mathrm{C}$. Their results suggest insignificant to very small increases ( 0 to $5 \%$ ) in permeability occurred during heating. Similar increases in permeability were measured in this study during the heating of samples 657 and 703 (Figures 7 and 8) up to $180^{\circ} \mathrm{C}$.

Somerton, Mehta and Dean (1965) cycled samples of St. Peter sandstone between room temperature and $800^{\circ} \mathrm{C}$ at confining pressures of $1 \mathrm{~atm}$. (0.1 MPa) and $1500 \mathrm{psi}(10.3 \mathrm{MPa})$ and measured air permeabilities before and after heating. At both pressures, samples cycled once between room temperature and $300^{\circ} \mathrm{C}$ exhibited permanent permeability losses on the order of $20 \%$. Samples cycled above $400^{\circ} \mathrm{C}$ exhibited increases in permeability, 
the result of structural damage and differential expansion of the quartz matrix (Somerton, Mehta and Dean 1965). In the temperature cycling experiments of this study, the permeability of St. Peter sandstone decreased $12 \%$ after one cycle and about $20 \%$ after three cycles. The lower permeability reduction ( $12 \%$ ) measured in this study as compared to the work of Somerton, Mehta and Dean (1965) after one temperature cycle may be the result of the lower maximum temperature $\left(180^{\circ} \mathrm{C}\right)$ or differences in physical properties of the St. Peter sandstone sample studied.

The permanent permeability reduction may result from the inelastic alteration of the sandstone matrix caused by the temperature cycling. Simultaneous determination of sandstone deformation using strain measurements during the temperature cycling process would have been beneficial in interpreting these results.

\section{EFFECT OF PORE PRESSURE}

The effect of pore pressure on permeability was studied within the narrow range of air injection pressures proposed in the Pittsfield test. Measurements of permeability at different pore pressures were obtained on only one sample (703), and this experiment (5) was performed prior to the temperature cycling experiments as discussed in the previous section (Experiment 4). Permeability was measured between 20 and 300 psi pore pressure $(0.14$ to $2.07 \mathrm{MPa})$ at a hydrostatic confining pressure of 1200 psi $\left(8.3 \mathrm{MPa}\right.$ ) and a temperature of $20^{\circ} \mathrm{C}$. Therefore, the effective stress range was 1 imited to 900 to 1180 psi.

The results (Figure 9) suggest very small changes in permeability occurred in the effective pressure range of 900 to 1180 psi (6.2 to 8.1 $\mathrm{MPa}$ ) as the pore pressure was increased. No particular trend is indicated as the data appear to be randomly scattered around a permeability of 600 md. Although the data suggest changes in permeability under these conditions are small, this does not preclude increases in permeability at higher pore pressures for some constant value of confining stress (i.e., 
lowering $\left.P_{e}\right)$. The condition of higher pore pressure may be valid for application of CAES in deeper reservoirs where air storage pressures may be near 2000 psi (13.8 MPa) (Allen et al. 1983). As an example, the data of Zoback and Byerlee (1975) suggest that the permeability (perpendicular to the bedding) of Berea sandstone continuously increases at constant confining stress as the pore pressure was increased from 3.5 to $20.0 \mathrm{MPa}$. The behavior of the St. Peter sandstone in the current experiment may be the result of the low pore pressure used or the very small amount of compressible clays in the matrix of this clean sandstone. Based on these results, little change in the permeability of the reservoir sandstone should be expected within the low injection pressure range $(<300 \mathrm{psi}$ ) of the CAES Pittsfield experiment.

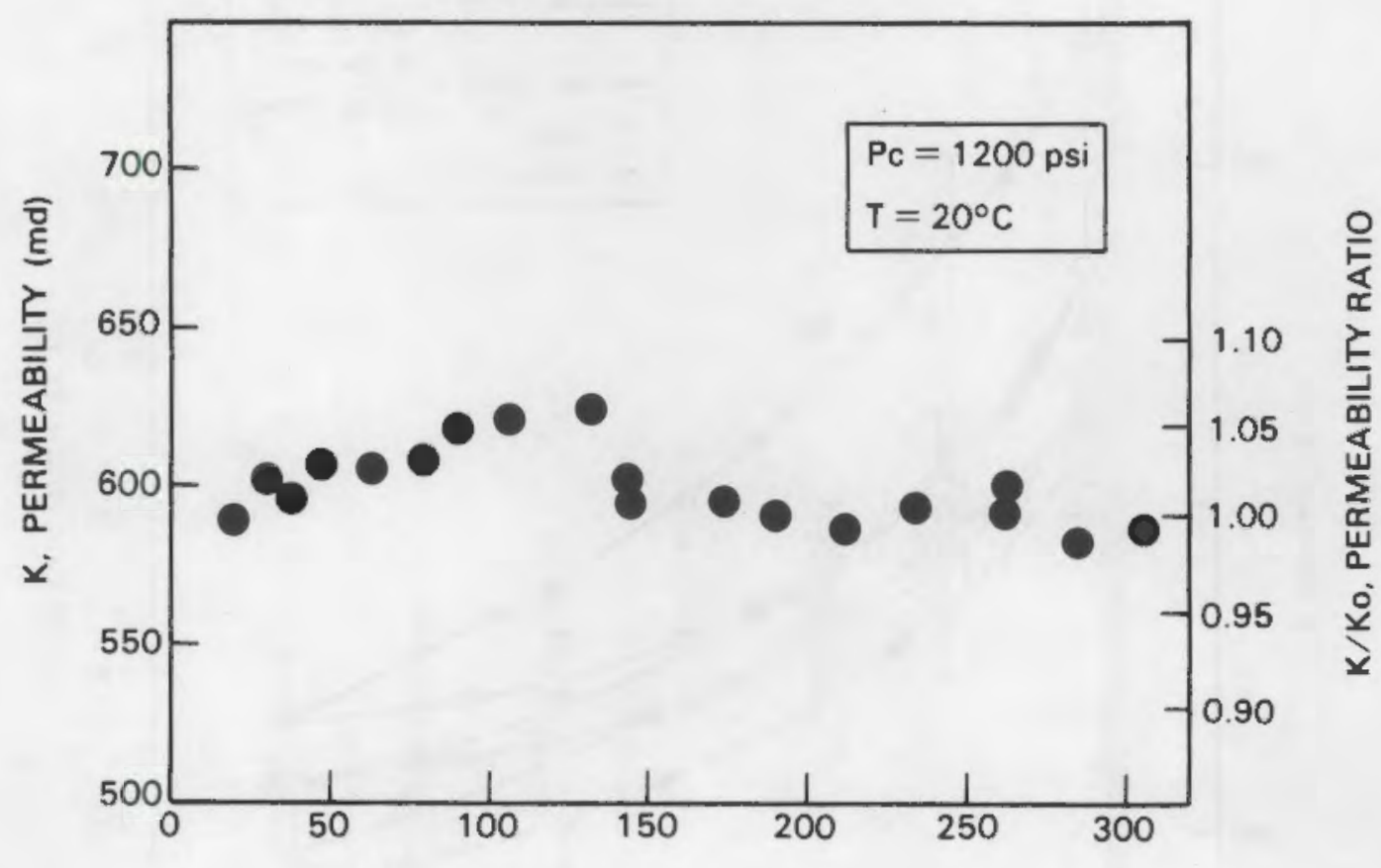

Pp, PORE PRESSURE (psi)

FIGURE 9. Permeability Versus Pore Pressure for Sample 703 


\section{EFFECT OF CONFINING STRESS ANO STRESS CYCLING}

The effect of stress and stress cycling on the permeability of one sample of St. Peter sandstone was determined in Experiment 6 . For this experiment, the sample was cycled three times between 1000 to 7000 psi (6.9 to $48.3 \mathrm{MPa}$ ) confining stress at a constant pore pressure of $300 \mathrm{psi}$ (2.1 $\mathrm{MPa}$ ) and temperature of $20^{\circ} \mathrm{C}$. The permeability data obtained in this stress-cycling experiment are illustrated in Figure 10. The data points and error bars represent the mean permeability plus or minus one standard deviation of a minimum of 25 measurements obtained at each isobar.

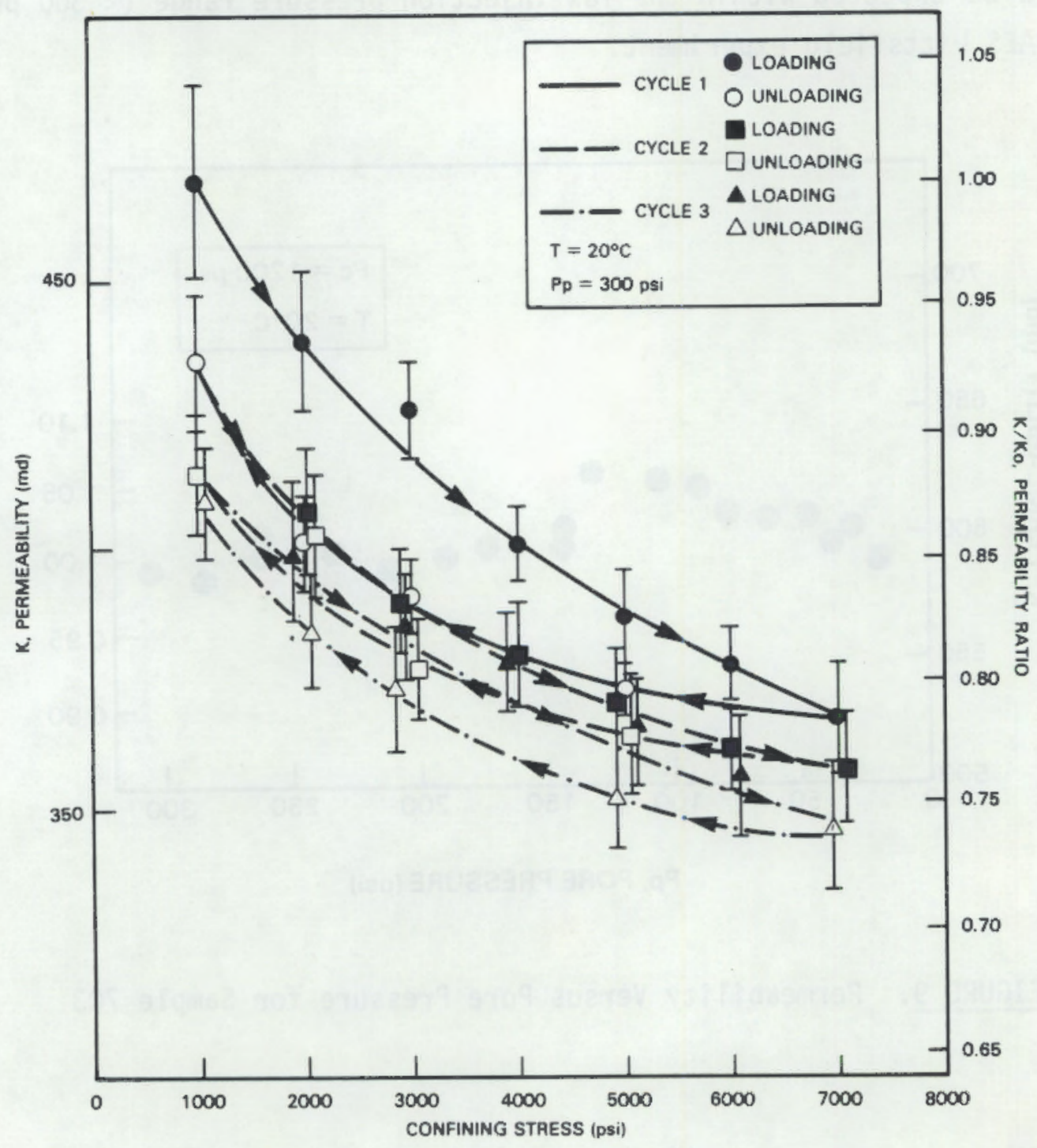

FIGURE 10. Permeability Versus Confining Stress for Sample 664 
The results show a decrease in the initial permeability ( $K_{0}=470 \mathrm{md}$ ) as the confining stress is increased. The average permeability reductions measured at $6700 \mathrm{psi}(46.2 \mathrm{MPa}$ ) effective stress for the three loading curves were $22 \%, 17 \%$, and $14 \%$, respectively. Moreover, the largest reduction in permeability occurs at the lower confining stresses. This type of behavior has been reported previously for numerous sandstones by Fatt and Davis (1952); McLatchie, Hemstock and Young (1958); Wyble (1958); Dobrynin (1962); Gray, Fatt and Bergamini (1963); Wilhelmi and Somerton (1967); Thomas and Ward (1972); Zoback and Byerlee (1975); and Nur et al. (1980) for different fluids including oil, water, nitrogen, and air.

The data in Figure 10 also suggest a hysteresis in permeability as indicated by the differences in permeability measured on the loadingunloading curves as well as a permanent permeability loss after each complete cycle. This hysteresis and inelastic behavior may indicate that some irreversible (inelastic) deformation occurred to the sandstone matrix during multiple stress cycles. Moreover, the hysteresis and permeability reduction is greatest for cycle 1 and decreases in magnitude with subsequent cycling. The nonrecoverable permeability loss between the second and third loading-unloading cycles is very small. In fact, differences in permeability measured between the loading-unloading curves of the second and third cycles are often within the error of the measurements (Figure 10). This decrease in magnitude of the hysteresis during the second and third cycles indicates that the damage mechanism may be self-limiting with further cycling. Permeability hysteresis during loading and unloading has also been reported for other sandstones by McLatchie, Hemstock and Young (1958); Thomas and Ward (1972); and Nur et al. (1980).

Values of axial strain were also determined during the stress cycling in Experiment 6 . The stress-strain behavior for the three cycles illustrated in Figure 11 shows the increases and consequent decreases in axial strain as the sample was loaded and unloaded between 700 to 6700 psi (4.8 to $46.2 \mathrm{MPa}$ ) effective confining stress. The curves in Figure 11 exhibit several characteristics that are similar to the permeability-stress data 


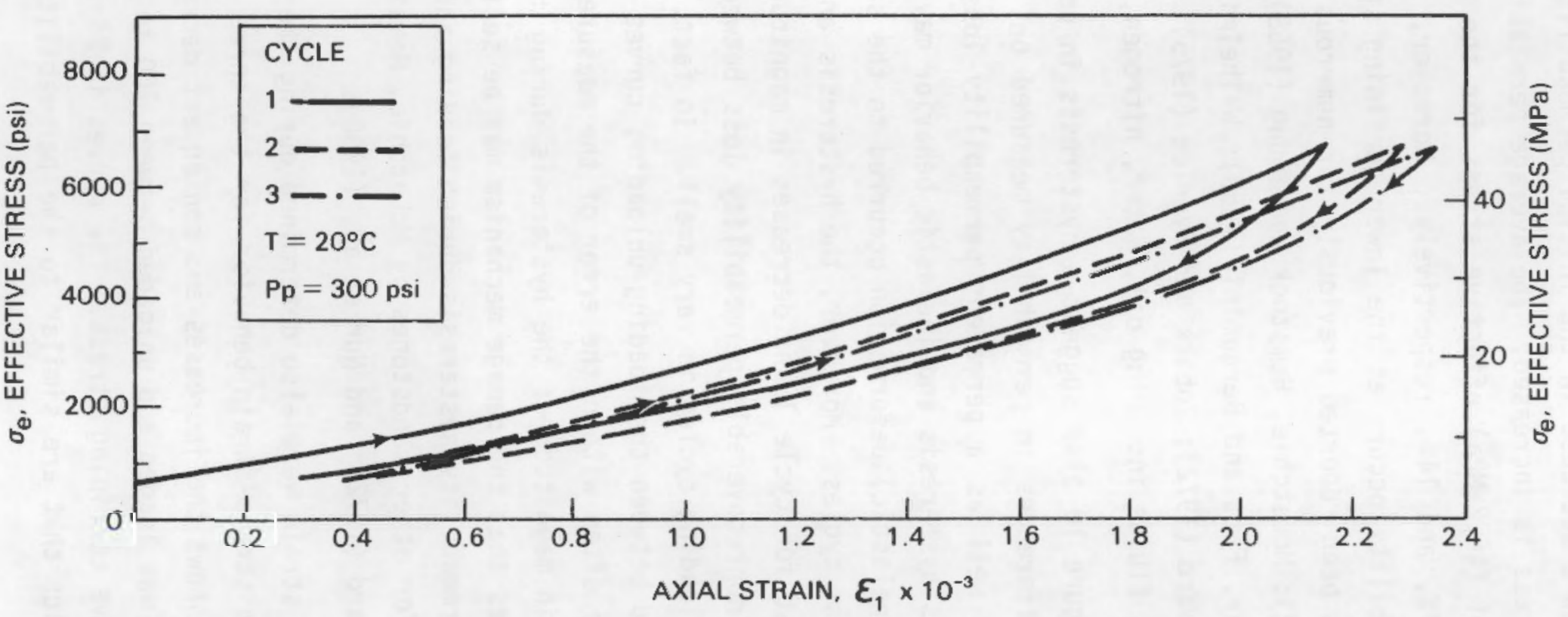

FIGURE 11. Axial Strain Versus Effective Stress for Sample 664 
suggesting the measured changes in permeability are, in part, related to the mechanical properties of the sandstone.

The individual stress-strain curves for all three cycles are slightly convex toward the strain axis, which is characteristic of "strain-hardening" behavior. This behavior is common for sandstones uniaxially stressed perpendicular to the bedding (Lama and Vutukuri 1978). Similar behavior in triaxial tests has also been reported for Boise sandstone (Fatt 1958a), Bandera sandstone (Wilhelmi and Somerton 1967), and previous measurements on St. Peter sandstone (Cleary 1959). Moreover, the slope of the stressstrain curves also suggest that the elastic modulus (E) in compression is increasing at higher effective stresses. For example, typical values of the elastic modulus (tangent modulus) for the loading curve of cycle 1 (Figure 11) increase from approximately $1.8 \times 10^{6} \mathrm{psi}$ to $4.0 \times 10^{6} \mathrm{psi}$ between 1000 to $6000 \mathrm{psi}(6.9$ to $41.4 \mathrm{MPa})$ effective confining stress. This trend and the calculated values of the tangent modulus (E) are also consistent with data for the elastic properties of Berea, Bandera, and Boise sandstone (Cleary 1959). The increased rigidity at higher effective stress results in less deformation of the sandstone and assuming a deformation-linked mechanism for permeability alteration, smaller permeability changes at the higher effective stresses (Wilhelmi and Somerton 1967). This mechanical behavior of St. Peter sandstone is consistent with the permeability data obtained in this experiment because the largest permeability reduction occurs at low confining stress (Figure 10 ).

A comparison of axial sample strain at any effective stress isobar for each consecutive stress cycle (Figure 11 ) suggests the strain values increase slightiy with each subsequent cycle. This indicates the sample is compressed more with each stress cycle. Assuming the cyclic changes in hydrostatic compression cause further deformation and reduction in sample pore volume with each cycle, this strain behavior also appears to be consistent with the permeability data. The permeabitities continuously decrease with each complete stress cycle (Figure 10). The data of 
Dobrynin (1962), who found a positive correlation of permeability reduction with increased pore volume compressibility as a function of effective stress, support this view.

The strain data for sample 664 (Figure 11) also exhibit a hysteres is upon unloading that is similar to the permeability hysteresis with load cycling (Figure 10). The strain of this sample is inelastic because of the permanent (inelastic) set measured for the three cycles after unioading. As was the case for the permeability-stress behavior, the strain hysteresis and permanent set is greatest for the first cycle and diminishes for each subsequent cycle. Moreover, the measured axial strains for the unloading curves of cycles 2 and 3 are nearly identical below an effective stress of $3000 \mathrm{psi}(20.7 \mathrm{MPa})$, indicating the strain behavior becomes more elastic with repeated stress cycling. The inelastic behavior (permanent set) and strain hysteresis exhibited by sample 664 has been reported for other samples of St. Peter sandstone (Cleary 1959) as well as for Bandera sandstone (Wilhelmi and Somerton 1967). In all cases, the strain behavior of these sandstones became more elastic with each loadingunloading cycle. Wilhelmi and Somerton (1967) reported five cycles (up to $P_{e}=12,000$ psi) were required before samples of Bandera sandstone behaved elastically. It has been suggested (McLatchie, Hemstock and Young 1958; Fatt 1958a; Thomas and Ward 1972) that this permeability-stress-strain hysteresis behavior is dependent on the stress history of the rock. Moreover, it may simply be the result of the removal of the core from the in-situ stress conditions present in the field.

The similarities of the mechanical and permeability behavior for the three loading-unloading cycles indicate these two properties appear to be related. Hysteresis and inelastic set effects were measured for both permeability and axial strain as a function of simulated hydrostatic overburden pressure in an aquifer reservoir. The most likely explanation for the permeability-stress behavior under these cyclic stress conditions is changes in the pore volume compressibility that effectively control rock permeability (Oobrynin 1962; Fatt 1958a; Somerton 1974). 
The permeability reductions (13\%) measured after three stress cycles are probably not large enough to significantly reduce the performance of the reservoir if the rock matrix maintains its structural integrity. The strain-permeability data of the one sample of St. Peter sandstone studied imply severe matrix degradation did not occur. Furthermore, all samples cycled within the temperature-effective stress conditions of this study exhibited no evidence of grain spalling, increases in friability, or other forms of physical degradation. If the five downhole samples studied are characteristic of the reservoir volume of the injection zone at Pittsfield, the environmental conditions of CAES should not adversely affect the physical nature of the sandstone. 
. 


\section{REFERENCES}

Afinogenov, Y. A. 1969. "How the Liquid Permeability of Rocks is Affected by Pressure and Temperature." Translated from SNIIGIMS, Novosibirsk. 6:34-42.

Allen, R. D., and T. J. Doherty. 1982. "The Aquifer Compressed Air Field Experiment at Pittsfield, Illinois." In Proceedings of the International Conference on Underground Pumped Hydro and Compressed Air Energy Storage, pp. 215-222, AIAA CP 826, American Institute of Aeronautics and Astronautics, New York, New York.

Allen, R. D., T. J. Doherty, R. L. Erikson and L. E. WiTes. 1983. Factors Affecting Storage of Compressed Air in Porous Rock Reservoirs. PNL-4707, Pacific Northwest Laboratory, Richland, Washington.

Aruna, M. 1976. The Effects of Temperature and Pressure on Absolute Permeability of Sandstones. PhD Dissertation, Stanford University. Palo Alto, California.

Casse, F. J. 1975. The Effect of Temperature and Confining Pressure on Fluid Flow Properties of Consolidated Rocks. PhD Dissertation, Stanford University. Palo Alto, California.

Cleary, J. M. 1959. "Hydraulic Fracture Theory, Part III - Elastic Properties of Sandstone." Circular 281, I1linois State Geological Survey.

Crane Co. 1965. "Flow of Fluids Through Valves, Fittings, and Pipe." Technical Paper No. 41D, Crane Co., Chicago, Illinois.

Danesh, A, C. Ehlig-Economides and H. J. Ramey, Jr. 1978. "The Effect of Temperature Level on Absolute Permeability of Unconsolidated Silica and Stainless Steel." Geothermal Resources Councit Transactions. 2:137-139.

Dobrynin, V. M. 1962. "Effect of Overburden Pressure on Some Properties of Sandstones." Soc. Pet. Eng. Jour. 2:360-366.

Fatt, I. 1958a. "Compressibility of Sandstones at Low to Moderate Pressures." Bull. Am. Assoc. Petrol. Geol. 42:1924-1957.

Fatt, I. 1958b. "Pore Volume Compressibilities of Sandstone Reservoir Rocks." Trans. AIME. 213:362-364.

Fatt, I., and D. H. Davis. 1952. "Reduction in Permeability with Overburden Pressure." Trans. AIME. 195:329. 
Folk, R. L. 1968. Petrology of Sedimentary Rocks. Hemphili's, Austin, Texas.

Franklin, J. A. 1972. "Suggested Methods for Determining Water Content, Porosity, Density, Absorption and Related Properties and Swelling and Slake-Durability Index Properties." Comunission on Standardization of Laboratory and Field Tests, International Society for Rock Mechanics.

Garg, S. K., and A. Nur. 1973. "Effective Stress Laws for Fluid-Saturated Porous Rocks." Jour. Geophys. Res. 78:5911-5921.

Gray, D. H., I. Fatt and G. Bergamini. 1963. "The Effect of Stress on Permeability of Sandstone Cores." Soc. Petrol. Eng. Jour. 3:95-100.

Hatsopoulos, G. N., and J. H. Keenan. 1965. Principles of General Thermodynamics. John Wiley and Sons, New York, New York.

Higdon, A., E. H. OhIson, W. B. Stiles, J. A. Weese and W. F. Riley. 1976. Mechanics of Materials. 3rd ed. John Wiley and Sons, New York, New York.

Jaeger, J. C. and N. G. W. Cook. 1976. Fundamentals of Rock Mechanics. 2nd ed. Halsted Press, New York, New York.

Keenan, J. H., F. G. Keyes, P. G. Hill and J. G. Moore. 1978. Steam Tables: Thermodynamic Properties of water Including Vapor, Liquid, and Solid Phases. John Wiley and Sons, New York, New York.

K1 inkenberg, L. J. 1941. "The Permeability of Porous Media to Liquids and Gases." Drill. and Prod. Prac. API:200.

Lama, R. D., and V. S. Vutukuri. 1978. Handbook on Mechanical Properties of Rocks - Testing, Techniques, and Results. Vol. II. Trans. Tech. Publications, CTausthat, Germany.

McLatchie, A. S., R. A. Hemstock and J. W. Young. 1958. "The Effective Compressibility of Reservoir Rock and Its Effects on Permeability." Trans. AIME. 213:386-388.

Newman, G. H. 1973. "Pore-Volume Compressibility of Consolidated, Friable, and Unconsolidated Reservoir Rocks Under Hydrostatic Loading." Jour. Petrol. Tech. 25:129-134.

Nur, A. M., J. D. Walls, K. Winkler and J. DeVilbiss. 1980. "Effects of Fluid Saturation on Waves in Porous Rock and Relations to Permeability." SoC. Pet. Eng Jour. SPE8235:450-458. 
PB-KBB Inc. and David K. Davies and Associates. 1983. Pre-Test Geological and Geochemical Evaluation of the Caprock, St. Peter Sandstone and Formation Fluids, Yakley Field, Pike County, Illinois. PNL-4564, Pacific Northwest Laboratory, Richland, Washington.

Pettijohn, F. J., P. E. Potter and R. Siever. 1972. Sand and Sandstone. Springer-Verlag, New York, New York.

Somerton, W. H. 1974. "Deformation Moduli of Water-Bearing Formations at Elevated Temperatures." Contribution No. 146, California Water Resources Center, University of California, Davis, California.

Somerton, W. H., M. M. Mehta and G. W. Dean. 1965. "Thermal A]teration of Sandstones." Jour. Pet. Tech. May 1965:589-593.

Sydansk, R. D. 198D. "Discussion of the Effect of Temperature and Confining Pressure on Single-Phase Flow in Consolidated Rocks." Jour. Pet. Tech. August 1980:1329-1330.

Thomas, R. D., and D. C. Ward. 1972. "Effect of Overburden Pressure and Water Saturation on Gas Permeability of Tight Sandstone Cores." Jour. Pet. Tech. February 1972:120-124.

Walsh, J. B. 1981. "Effect of Pore Pressure and Confining Pressure on Fracture Permeability." Int. J. Rock Mech. Min. Sci. and Geomech. Abstr. 18:429-435.

Weast, R. C. 1971. Handbook of Chemistry and Physics. 52nd ed. CRC Press, Cleveland, ohío.

Weinbrandt, R. M. 1972. The Effect of Temperature on Relative Permeability. PhD Dissertation, Stanford University. Palo Alto, California.

Weinbrandt, R. M., H. J. Ramey, Jr., and F. J. Casse. 1975. "The Effect of Temperature on Relative and Absolute Permeability of Sandstones." Jour. Pet. Tech. October 1975:376-384.

Wilhelmi, B., and W. H. Somerton. 1967. "Simuitaneous Measurement of Pore and Elastic Properties of Rocks under Triaxial Stress Conditions." Soc. Petrol. Eng. Jour. 7:283-294.

Wyble, D. 0. 1958. "Effect of Applied Pressure on the Conductivity, Porosity, and Permeability of Sandstones." Trans. AIME. 213:430-432.

Zoback, M. D., and J. D. Byerlee. 1975. "Permeability and Effective Stress." Am. Assoc. Petrol. Geol. Bull. 59:154-158. 


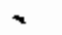

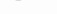

4 


\section{DISTRIBUTION}

No of

Copies

\section{OFFSITE}

US Oepartment of Energy

Attn: J. Brogan

Office of Energy Systems Res.

Forrestal B1dg, CE-141 5E-052

Washington, DC 20585

US Department of Energy

Attn: R. A. Dunlop

Div. of Electric Energy Sys.

12 \& Pennsylvania

Washington, DC 20585

US Department of Energy

Attn: I. Gyuk

Office of Energy Systems Res.

Forrestal Bldg, CE-141 5E-052

Washington, DC 20585

US Department of Energy

Attn: R. Shivers

Office of Energy Systems Res.

Forrestal B1dg, CE-141 5E-052

Washington, DC 20585

27 DOE Technical Information Center

Acres Anerican, Inc.

Attn: C. Driggs

The Clark Building

Suite 329

Columbia, MD 21044

Acres American, Inc.

Attn: D. Willett

Liberty Bank Building

Main at Court

Buffalo, NY 142D2
No of

Copies

Central Illinois Public Service Co.

Attn: A. H. Warnke

Vice President Power Supply

607 East Adams Street

Springfield, IL 62701

Comrnonwealth Edison Co.

Attn: T. J. Maiman

Sta. Mech. Engr. Dept. Mgr.

36 FN West

PO Box 767

Chicago, IL 60690

c. V. Crow

76 Colorado Drive

Decatur, IL 62526

Electric Power Research Inst.

Attn: R. B. Schainker

3412 Hillview Avenue

PO Box 10412

Palo Alto, CA 94303

Harza Engineering Co.

Attn: A. H. Barber

Director of Marketing

150 5. Wacker Drive

Chicago, IL 60606

Michae] J. Hobson

PO Box 820

Columbia, MD 21044

ITlinois Power Company

Attn: G. E. Huck

Manager of Planning

500 South 27 th 5 t.

Decatur, IL 62525

Michael King

365 Vatlejo \#1D

San Francisco, CA 94133 
No of

Copies

Lawrence Livermore Laboratory

Attn: Jesse Yow

PO Box 808

Mail Stop L-202

Livermore, CA 94550

Lawrence Livermore Laboratory

Attn: Tech. Info. Dept, L-3

University of California

PO Box 808

Livermore, CA 94550

Middle South Services

Attn: L. A. Wilson

Advanced Energy Program

Section

Box 6100

New Orleans, LA 70161

$\mathrm{PB}-\mathrm{KBB}$, Inc.

Attn: J. Istvan

PO Box 19672

Houston, TX 77024

Potomac Electric Power Co.

Attn: P. E. Schaub

1900 Pennsylvania Ave

Washington, DC 20006

Public Service of Indiana

Attn: T. W. McCafferty

$1 D 00 \mathrm{E}$. Main Street

Plainfield, IN 46768

RE/SPEC Inc.

Attn: A. F. Fossum

PO Box 725

Rapid City, SD 57701

Neilson Rudd

PO Box 176

Put-in-Bay, OH 43456
No of

Copies

Sandia Laboratories

Attn: William G. Wilson

PO Box 969

Organization 8453

Livermore, CA 94550

Sargent and Lundy Engineers

Attn: W. C. Walke

Project Manager

55 East Monroe Street

Chicago, IL 60603

Soyland Power Cooperative, Inc.

Attn: Tom Seng

P0 Box A1606

Decatur, IL 62525

Tennessee Valley Authority

Attn: A. Betbeze

1150 Chestnut, Tower 2

Chattanooga, TN 37401

Tennessee Valley Authority

Energy Research Section

1360 Commerce Union Bank

B1dg.

Chattanooga, TN 37401

TRW Energy Systems Group

Attn: E. Berman

Technical Library

7600 Colshire Drive

McLean, VA 22101

Union Electric Co.

Attn: H. C. Allen

Vice President

Research \& Development

PO Box 149

St. Louis, M0 63166 
No of

Copies

United Engineers \&

Constructors

Attn: E. Sosnowicz

Advanced Eng. Dept. 04U3

30 South 17th

Philadelphia, PA 19101

University of California

Attn: T. L. Brekke

Dept. of Civil Engineering

1847 Yosemite Road

Berkeley, CA 94707

University of Massachusetts

Attn: 0. C. Farquhar

Dept. of Geology \& Geography

Morrill Science Center

Amherst, MA 01003

University of Michigan

Attn: D. L. Katz

Dept. of Chemical Engineering

2042 E. Engr. Bldg.

Ann Arbor, MI 48109

University of Wisconsin

Attn: H. J. Pincus

Dept. of Geological Sciences

Sabin Hall and Greene Museum

PO Box 413

Milwaukee, WI 53201

U.S. Department of Interior

Attn: Lucy Howton

Natural Resources Library

Serial Branch

Gifts and Exchange Division

Washington, DC 20240

Westinghouse Electric Corp.

Attn: W. F. Kobett

CAES Project Manager

Combustion Turbine Sys. Div.

Long Range Develop-Lab 100

P0 Box 251

Concordville, PA 19331
No of

Copies

Westinghouse Fluid Sys Lab

Attn: 3. Y. Baladi

1291 Cumberland Avenue

West Lafayette, IN 47906

Westinghouse R\&D

Attn: D. L. Ayers

1310 Beulah Road

Pittsburg, PA 15235

\section{FORE IGN}

Central Electricity Generating Board

Attn: I. Glendenning

6 Georgian Close

Gloucester England

$9 L 4$ 9DG

ONSITE

DOE Richland Operations Office

H. E. Ransom/D. R. Segna

42 Pacific Northwest Laboratory

R. D. Allen

S. C. Blair

T. J. Doherty

R. L. Erikson (10)

L. D. Kannberg (20)

J. A. Stottlemyre

L. E. Wiles

Technical Information (5)

Publishing Coordination (2) 
